\title{
Os Guarani: Índios do Sul Religião, Resistência e Adaptação*
}

\section{CARLOS RODRIGUES BRANDÃO**}

$\mathrm{P}$ ois é isto, meus irmãos, minhas irmãs, para obtermos as normas de obstinaçáo, para que nós chegássemos à completude nós nos erguemos no esforço.

Como deveremos nos conduzir à verdade? O que disse, na verdade, Nhande Ru Papari?

Como ele viveu, na verdade?

Como Nhande Ru Papari, para o seu próprio futuro tão bem soube, na verdade?

Conformemente a isso, de novo vamos nos conduzir meus irmãos, minhas irmãs.

Graças a isso já nos erguemos no esforço com o bastão - insígnia que Nhande Ru Carai Ete concebeu

Nós o brandimos, nós nos abaixamos, nós nos reerguermos, nós - os eleitos.

\section{Palavras dos uiltimos dentre os eleitos fragmento \\ 1 - Quantos Eram? Quantos São?}

Pierre Clastres reconta os Guarani do passado. Ele discute a difícil questáo da demografia indígena e em absoluto náo concorda com as cifras até entáo calculadas, do mesmo modo como outros antropólogos mais recentes não concordam com as dele. Seriam muito mais, pouco anos antes do início da conquista, estes índios do Sul,

* Documento preparado para o Programa de Investigação: Palavra e Obra no Novo Mundo: Imagens e Afóes Interétnicas. Trujillo, Espanha, Dezembro de 1988.

* Carlos Rodrigues Brandão é professor do Departamento de Ciências Sociais da Unicamp e da FFLCH/USP. É autor de Identidade e Etnia (São Paulo, Brasiliense, 1986); Festim dos Bruxos (Säo Paulo, fcone/Unicamp, 1987) e A Cultura na Rua (Campinas, Papirus, 1989). 
profetas errantes em busca sem fim da Terra Sem Mal. Antes do começo do genocídio dos Guarani, eles haveriam de ser pelo menos seis vezes mais do que os apenas 250.000 índios, por volta de 1570 , calculados por Rosenblantt, e mais de dez vezes os irrisórios 100.000 imaginados por Steward em anos próximos a 1530.

É necessário pois, para refletir sobre os Guarani, adotar esses dados fundamentais: eles eram, antes $\mathrm{da}$ Conquista, 1.500.000, repartidos por 350.000 $\mathrm{km}^{2}$, ou seja, uma densidade de pouco mais de 4 habitantes por quilômetro quadrado(l).

Năo é exatamente esta notável revisão de cifras o que chama a atenção. Algumas observaçóes sobre como esses guerreiros do Sul ocuparam o território de uma grande parte da América merecem, elas sim, destaque. Da mesma maneira como espanta lembrar que esses indígenas foram, como tantas outras naçóes, dizimados em uma proporção de 1 sobrevivente para cada $\mathbf{5 0 0}$ ou mais mortos. Por um longo tempo e depois da Conquista os tupi-guarani lograram preservar uma surpreendente uniformidade de língua, organização social e sistema de vida - o ñande reko, o "nosso modo de vida" dos Guarani - ao longo de um intenso território de florestas cujos limites iam da Amazônia à Bacia do Prata. Distâncias maiores de $4.000 \mathrm{kms}$, entre o Sul e o quase extremo Norte do continente, não tornariam muito diversificadas culturas de uma tão grande variedade de tribos tupi-guarani (2).

De saída reconheçamos que os próprios termos: tupi, guarani e tupi-guarani traduzem dimensóes diferentes, e nem sempre claras de povos, naçóes e tribos do passado e de hoje. Vejamos uma vez mais o próprio Pierre Clastres:

Os tupi-guarani apresentam a situação inversa: tribos, situadas a milhares de quilômetros uma das outras, vivem do mesmo modo, praticam os mesmos rituais, falam a mesma língua. Um Guarani do Paraguai se sentiria em terreno perfeitamente familiar entre os tupi do Maranhăo, distante entretanto 4.000 quilômetros(3).

(1) Clastres, Pierre, A Sociedade Contra o Estado, p. 48.

(2) Era este Nande Reko, o "nosso modo de ser" na antiga naçāo Guarani, a maneira peculiar de afirmaçăo de diferenças, não apenas como uma identidade construida, metáfora do " ser Guarani", mas como a realidaçáo deste ser através do cumprimento de princípios vitais, cotidianos da vida tribal. Ver o sentido desta expressáo em Meliá, Bartolomé: El Modo de Ser Guarani en la Primeira Documentación Jesuística, p. 5-6.

(3) Clastres, Pierre, A Sociedade Contra o Estado,p. 58. 
Mas ao contrário dos outros tupi que os missionários e viajantes-cronistas da "Conquista do Brasil" iriam encontrar espalhados por uma ampla área litorânea e, depois, continental de florestas da América do Sul, viviam os Guarani dentro de um território bastante mais delimitado. Isto muito embora eles fossem, desde antes da chegada das caravelas, grupos indígenas sempre nômades em busca da Terra Sem Mal. A regiäo Guarani do passado delimitava-se originalmente a Oeste do rio Paraguai e ao Sul da confluência deste rio com o Paraná. O Oceano Atlântico era o seu limite oriental, entre Paranaguá, no litoral brasileiro e a fronteira entre - Brasil e o Uruguai de hoje. De um território, entre florestas e grandes rios, com pouco mais de $500.000 \mathrm{~km}^{2}$, os Guarani dominaram uma regiáo de pelo menos $350.000 \mathrm{~km}^{2}$. Concentrados pouco mais tarde basicamente nas imensidóes do Chaco, foram eles primeiro alidados dos espanhóis durante as primeiras investidas da Conquista, entre Assunção c os Andes. Foram depois reduzidos pelos padres jesuítas e esta experiência é conhecida o bastante para ser repetida aqui. Dentro ou fora das terras das missóes, foram mais tarde dizimados e reduzidos à escravidáo pelas encomiendas espanholas. E pelas campanhas genocidas de portugueses e bandeirantes paulistas(4).

Embora pareça cientificamente estranho, não é fácil dizer-se quantos são os Guarani de agora, entre a Argentina e o Paraguai, a Bolívia e o Brasil. Năo é fácil sequer definir quem eles são.

Segundo Egon Schaden, à exceção dos Guayaki, um grupo nômade do Paraguai que nos espera adiante, a população Guarani do oeste deste país; da Argentina, do Brasil, pode ser em princípio dividida em 3 subtribos: os Nandeva, também conhecidos como Xiripá, os Mbiá (Mbuá, Mbwá, Mbyá) e os Kaiowá. No Paraguai é preciso desdobrar os Guarani em outros e sub-grupos ainda. Os Xiripá (Chiripá) estendem-se pelo norte, ao longo da rodovia Strossner-Assunción e somam cerca de 3.000 índios, de acordo com Miguel Chase-Sardi, ou 6.500 , segundo J. Borgson. Esses seriam os Guarani mais aculturados

(4) De qualquer maneira as cifras do genocidio indígena sāo no Sul do Continente mais brandas - se é que este termo pode ser aplicado ao que ocorreu - do que em regióes da Conquista na América do Norte, especialmente no México. De acordo com os pesquisadores de Berkeley em que Pierre Clastres se baseia, na regiāo de Anauaque 25.000.000 índios em 1500 reduzem-se drasticamente a cerca de $1.000 .000 \mathrm{em} 1605$. O Império Inca despovoa-se de 10.000 .000 para 1.000 .000 de pessoas entre um período equivalente de 100 anos, isto $k$, de 1500 a 1600 . Uma queda de $9 / 10$, terrivel, mas ainda melhor do que a da conquista do México, cuja proporçáo para o mesmo perfodo é de 96/100. Mas a partir desta despopulação geométrica há, nos Andes... em algumas áreas do México e da América Central, uma lenta recuperaçāo demográfica indígena. O mesmo năo acontece em momento algum no caso Guarani. Depois de haverem sido já muito reduzidos, dentro e fora das Missóes, os Guarani passam de $200.000 \mathrm{em} 1690$ para $130.000 \mathrm{em} 1730$. E decrescem sempre. A Sociedade Contra 0 Estado, p. 67-8. 
da regiáo oriental do Paraguai. Os Guayaki (Aché, Aché-Guayaki) săo índios nômades e caçadores. Habitantes de seis zonas do Chaco

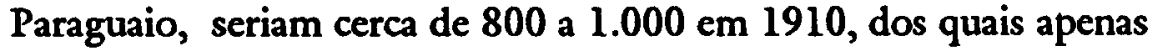
uns 500 escaparam de uma epidemia de gripe em 1920. Já na década de 1960 não seriam mais do que cerca de 350 pessoas. Pouco mais de 1.000 índios Guarayo, que se autodenominam de nafão Guarani e são por outros considerados como índios Chané guaranizados, vivem no extremo norte do Paraguai(5).

Os Mbiá (também Mbihá, Ave-Mbihá, Cacyguá, Pitará, Baticol, Caiinguá, Kaynguá, Mbyá-Apitaré, Avé-Mbyá) que se autodenominam Jagua Teonde Paraguai (Cadogan, 1968) sáo possivelmente o subgrupo Guarani mais disseminado. Vivem no território de Missiones, na Argentina, entre serras e florestas nos estados já mencionados do território brasileiro e em boa parte do Departamento de Guayra, no Paraguai(6).

Seriam os Paí Tavytera o subgrupo Guarani mais populoso do Paraguai? Provavelmente sim, pois há deles ainda algo como entre 9.000 e 11.000 pessoas, ao norte do rio Jujui, na fronteira setentrional e leste do Paraguai com o Brasil, onde há também alguns núcleos destes índios também chamados Pań, Teranole (Metraux), Kaaygua e, contra a vontade deles próprios, Cayuá ou Caiová, finalmente, Abá.

Índios que se atribuem o nome Avá (homem) e rejeitam o nome com que sáo mais conhecidos, Tapieté (também Tapii, Yaanayge, Yane, Nanaigua, são cerca de $\mathbf{2 . 0 0 0}$ pessoas ao noroeste do Chaco e no extremo oeste do Paraguai. Há também Avá-Tapieté na Bolívia(7).

Alguns autores lembrarão, entre os grupos indígenas náo-andinos da Bolívia, os Chiriguano, "índios guaranizados". Mas em seu estudo sobre os grupos indígenas da Bolívia, Heinz Kelm lista outros sete grupos Guarani e um Arawac-Guarani: Chane, Chiriguano, Guarayú, Jore, Pauserna (Guarasuyuna), Siriono, Tapiete, Yuqui (Sirioco). Os Chane não săo mais do que 20 índios Arawac-Guarani situados ao sudeste de Santa Cruz de la Sierra. Menos ainda, os Jora seria 8 sobreviventes entre os rios são Simão e Iténez. Os Pauserna,

(5) Chase-Sardi, Miguel, La situación actual de Los Indígenas en el Paraguai, in: W.Dostal e G. Grumberg, La situación del indígena en América del Sur, 1971.

(6) Cadogan acredita que " atualmente os Mbyá encontram-se em grupos disseminados e núcleos reduzidos, através dos departamentos de Itapuã, Caazapâ, Gucirā, Alto Paraná e San Pedro. Vi duas famlias em Misiones perto de Santa Rosa e periodicamente alguns passam a Misiones argentinas e ao Mato Grosso" . "Encontramos Mybiás nas ruas de São Paulo. Eram os que vivem em Iranhaém, de que Baldus nos dá notícia. Chase-Sardi, Miguel, Situación Actual de los Indtgenas en el Paraguany, p. 237-306. Citado na p. 277.

(7) Chase-Sadi, Miguel, La Situación Actual de los Indígenas en el Paraguay, p. 242. 
sobreviventes entre o rio Pauserna, o Paraguá e o Hénez, oscilam entre 28 e 30 pessoas. Sáo menos numerosos do que os Tapieté, que encontramos antes no Paraguai e que, na Bolívia, náo são mais do que 40 pessoas, entre as margens do rio Pilcomayo e a fronteira com o Paraguai. Os Yuqui são cerca de 50 índios ao sul do alto rio Ichilo(8).

Entre os Guarani ou índios guaranizados com uma populaçáo melhor preservada, é preciso contar os Sirioco, com um número entre 500 e 800 índios, distribuidos pelo rio San Martin e Negro, no departamento de Beni, o alto rio Machupo e Missiones de Guarayos a noroeste de Santa Cruz de la Sierra. Os Guarayú seriam cerca de $\mathbf{5 . 0 0 0}$ índios entre o rio San Pablo e o Blanco a noroeste de Santa Cruz. Finalmente, os Chiriguano são entre 15.000 e 20.000 índios Guarani, espalhados pela região de extensas serranias entre o sudoeste de Tarijá e o Paraguai.

Em termos númericos é possível que, tal como acontece na Bolívia, o grupo Guarani mais importante na Argentina seja o dos Chiriguano, vindos do Paraguai desde tempos remotos da Colônia. Hoje eles se dividem em 54 sub-grupos distribuídos pelos departamentos de Jujui (El Caiman, Laderma, San Pedro e Santa Bárbara) e de Salta (Orăn e San Martin). Somam um total aproximado de 14.000 pessoas.

Os Mbiá que encontramos no Brasil e no Paraguai são, na Argentina, cerca de apenas 600 indivíduos; pouco menos de 1.000 , de acordo com outras estatísticas. Migraram do Paraguai para a província de Missiones depois de 1870 e hoje distribuem-se em cerca de 28 comunidades(9). Os Chané (Guaná) constituem na Argentina, tanto quanto na Bolívia, um grupo Arawac guaranizado pelos chiriguanos. São pouco menos de 900 índios na província de Salta(10).

(8) Kelm, Heina, Grupos Indigenas de Bolíia, p. 232-4.

(9) Bartolomé, Miguel Alberto, Grupos Indígenas en la Argentina - drea Machagueña e Misiones, p. 347-9.

(10) No já quase envelhecido, mas ainda necessário Handbook of South American Indians, os Guarani aparecem nos volumes 3 e $6 \mathrm{com}$ um importante registro de Alfred Metraux. Estes antigos senhores de um território de dimensōes continentais, quando somados aos outros grupos tribais Tupi, são classificados ainda no período Colonial em duas categorias: $1^{a}$ os índios já entáo submetidos ao trabalho e ao controle religiosos das missōes jesuísticas; $2^{\mathrm{a}}$ os " índios livres", denominados Cainguá (Kaathwá, Kainguá, Cayauá) nomes que sempre querem significar algo próximo a "índios da floresta". Deixados de lado os índios " reduzidos", Metraux dividide os Cainguá em três grupos: Mbyá (Paraguai, Argentina e nos estados brasileiros de Mato Grosso, Paraná e Rio Grande do Sul), Chiripá, concentrados no Paraguai e os Pañ (Teranōhe), também no Paraguai. Também em Metraux os Mbiá seriam o subgrupo Guarani que melhor preservaria uma antiga cultura tribal, resistente aos valores regionais. Seriam os Chiripá os mais aculturados. Entre os Guarani Brasileiros, os Apapocuva seria índios Cainguá, de quem se conhecem, diversos homônimos no Paraguai. Ainda no Brasil outros subgrupos Cainguá: os Cainguá, propriamente, os Carimã, ...., Guayana, Tañiguá, Oquauiva, Cheirú, Yuytyiguá, Avachiropé, Catan- 


\section{2 - Xamãs e Profetas: a religião dos Guarani}

A Hélène Clastres alguns aparentes silêncios dos índios Tupi chamam a atenção. É que segundo os primeiros relatos de missionários e outros colonizadores, eles pareciam ser "gente sem lei": povos e culturas sem a idéia de um deus, sem o seu temor, sem mais nada do que vagos nomes dados a algum fenômeno da natureza. A própria noção do sagrado parecia ser desconhecida aos tupi-guarani. Alí estava uma gente que ao contrário de outros índios encontrados na rota dos descobrimentos, parecia náo possuir ritual algum de qualquer tipo de culto religioso. Não possuindo em aparência o conhecimento de um deus, não pareciam ter crença alguma em outros seres: maléficos ou demoníacos. E se aos primeiros jesuitas espantava uma "gente" sem fé, consolava a desconfiança de que, pelo menos entre eles, não seria necessário combater "falsas crenças", pois, a um primeiro olhar piedoso, parecia não haver nenhuma.
Depois do padre Manoel da Nóbrega e dos primeiros missionários, todos os viajantes que visitaram os índios coroboraram esta afirmação: não somente eles não tinham conhecimento algum do deus verdadeiro - o que, tratando-se de selvagens, a ninguém surpreendia - mas tampouco tinham falsas crenças. Esse traço notável das naçóes pós-guarani espanta - ainda que anime, pelo menos, os missionários: sua tarefa de evangelização vê-se simplificada, por náo terem de combater crenças já estabelecidas. Rebeldes à idéia corrente sobre o que deveriam ser os pagãos - adoradores de divindades múltiplas e praticantes de cultos idólatras - esses índios em nada acreditavam, não adoravam astros, nem animais, nem plantas, nem contando com padres ou lugares sacros(11).

"Gente sem fé", teriam dito dos tupi-Guarani os primeiros
missionários. "Teólogos da América do Sul", escreve-se hoje, com
alguma frequência, a respeito dos Guarani. Que religião afinal era a

du..., Jatahy, segundo relato de Kurt Nimuendaju, a maiona deles já extintos. Dentre todos, apenas os antigos Apapocuva, os Tañygua e os Oguaiuva somam de fato grupos parciais culturalmente guarani. Todos os outros seriam reconhecidos como Cheirú (Kainguá). Mesmo ao tempo de Kurt Nimuendaju, os Ivarapá (Aré, Sheté) seriam subgrupos linguísticos considerados como guarani errantes nas florestas do Brasil, do mesmo modo como os Guayaki nas selvas do chaco paraguaio. Em 1912 Nimuendaju estimara em cerca de $\mathbf{3 . 0 0 0}$ todos os índios Cainguá do Brasil. Ver Metraux, Alfred, South Americans Indians, p. 69-72.

(11) Clastres, Hélène, Terra Sem Mal, p. 14-5. 
Em que creêm

hoje e o que buscam? Em que as suas crenças se perderam do ritual antigo e da memória? No que se transformaram? deles? Em que creêm hoje e o que buscam? Em que as suas crenças se perderam do ritual antigo e da memória? No que se transformaram?

Deixemos de lado a síntese do sistema religioso dos antigos Tupi e concentrêmo-nos na descrição da religião Guarani(12). As palavras ñandé rekó, que vimos algumas páginas atrás como sinônimas de algo como "modo de ser", "o nosso modo de ser", que o Guarani emprega para dizer em que, como e porquê se reconhece diferente dos demais, designa-se também a religião. Isto é o mesmo que dizer que entre os seus sub-grupos, um modo peculiar de ser, assumido e proclamado como uma identidade realizada como um sistema ancestral de crenças destinado a conduzir tanto a história de um povo quanto a conduta cotidiana de cada uma de suas pessoas, é definido como uma religiāo. Esta seria uma das razóes pelas quais um mesmo sistema religioso, em princípio unívoco entre vários subgrupos e tribos, é bastante resistente a ponto de ser ainda quase integralmente a religiāo Guarani, após um tempo entre 450 e 300 anos de evangelização cristá(13). A oposiçáo entre esta resistência nativa e uma criativa incorporação de temas e sujeitos do cristianismo é o que nos obrigará a um segundo momento de descrição etnográfica, adiante.

Guardadas as diferenças entre as culturas do sub-grupos Guarani, o que Egon Schaden resume a respeito da religiáo estudada por ele entre os Kayaowá do Mato Grosso do Sul, poderia ser estendido aos outros grupos.

Um lugar intermediário, morada de inúmeros deuses e espíritos que habitam os seus vários sub-espaços superpostos e a que os Guarani dáo o nome de Yváraquy, existe entre a superfície da Terra onde vivem os humanos - $\Upsilon_{\text {vy- }} \Upsilon_{\text {pikatu }} \mathrm{e}$ algo equivalente ao firmamento, não exatamente pensado como um homem cristáo do povo imagina o céu de sua fé - Ypá, Yvága, Yvánga -. Entfe os dois lugares extremos,

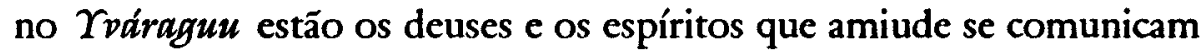
com os vivos e que podem ser benéficos ou perigosos.

(12) Há estudos, de resto conhecidos, a respeito da religião que os primeiros europeus encontraram entre os povos Tupi do Litoral Brasileiro. Entre as pesquisas mais atuais merece se lido inicialmente o A Religião dos Tupinambá, de Alfred Metraux. Do notável Leónd Cadogan é importante conhecer pelo menos o seu antigo trabalho de 1946: Las Tradiciones Religiosas de los Índios Jeguaka Tenondé Porá-qué i del Guairá comumente Ilamados Mbya, Mhya-Apyteré o Kayangud, originalmente editado pela Revista de la Sociedad Cientifica del Paraguay. O célebre trabalho de Kurt Nimuendajú a respeito dos mitos de criaçăo dos Apapokuva-Guarani - inexplicavelmente não publicado em tradução portuguesa até hoje - é um trabalho de referência obrigatória: Los mitos de creación y de destrucción del mundo como fundamentos de la religión de los Apapokupa-Guarani, editado em Lima pelo Centro Amazônico de Antropologia y Aplicación Prática. Finalmente, e ele será com frequência citado aqui, há o estudo realizado por Hégène Clastres sobre o sistema religioso guarani, com foco sobre o profetismo da Terra Sem Mal, que dá título ao seu livro.

(13) Schaden, Egon, Religião Guarani e Crisrianismo, p. 8. 
De acordo com certos sub-grupos Kayowá, Mbyá e Ñandeva, existe um deus supremo, um criador indiscutível do mundo terreno, sua ordem e a totalidade dos seus habitantes: Name Ramōi Papá. Os Kayowá do Amambabí, estudados por Egon Schaden, reconhecem em Nãmé Ramó Papá a pessoa de uma divindade suprema, mas não propriamente um criador. Um orvalho primitivo, $-\Upsilon_{\text {sapy }}-$ deu origem ao embrião da Terra - $\Upsilon_{\imath i}$ Reñoi - e também aos deuses que, tal como os humanos, surgiram de uma mesma "origem impessoal das coisas", criadora e náo criada por deus algum: Djasaká (14).

Um casal de deuses supremos - criadores, ordenadores ou não do mundo terreno - estabelecem com os homens uma distanciada relação afetivamente parental: Nané Ramói Papá é traduzido como" nosso avô", " nosso ancestral" e Nandé Djary, sua esposa mas não sua equivalente em poder e posição celestial - é traduzida como "nossa avó". Distribuidos por outras regiōes celestiais, deuses menores prestam serviços a Namé Ramôi Papá na qualidade de Ypyrtidjá, os "senhores dos pequenos bastōes".

Namé Ramōi possui deuses - filhos e entre eles merece destaque a pessoa de Pai Kwara, o deus lunar. É ele quem se relaciona com os homens $\mathrm{e}$, desde a região superior do centro do céu, dirige suas vidas terrenas. É a ele - ou a seu equivalente em outros sub-grupos - que Guarani se sente estabelecendo uma relação cuja traduçăo católica seria

(14) Toda a religião indígena que não afirme explicitamente a origem de " todas as coisas" e, no ponto central da criaçáo, a origem da própria tribo como o ato voluntário de um deus, de uma relação entre divindades ou entre seres humanos, forças divinizadas e a própria natureza, deixa margem a uma discussão interminável a respeito do sentido do próprio ato, ou da sequência de atos de origem. São forças impessoais da natureza? Serăo seres humanos punidos por seus deuses ou sacralizados como ancestrais místicos, devido ao seu gesto de origem? É um ser divino, mas apenas ordenador e, depois distanciado dos humanos, deixando a cargo de forças ou divindades intermediárias a responsabilidade do "cuidado do mundo e dos homens" ? É um ser divino pessoalizado e atento aos humanos, no sentido cristão da idéia de deus? A respeito dos TupiGuarani sabemos que a interpretaçáo de uma idéia de deus pessoal intrigava os europeus desde os primeiros cronistas e missionários. Afinal, em que criam os primeiros Tupi?

Mas, prossigamos na leitura: Claude d'Abbeville: "Embora os índios tupinambás tenham um juízo natural bastante belo, nunca se viu nação mais rebelde ao serviço de Deus do que eles... Não creio que haja nenhuma nação no mundo sem alguma espécie de religiāo, exceto os índios rupinambás, que até hoje não adoraram a Deus Algum, nem celeste, nem terrestre, nem de ouro, nem de prata, nem de pedra preciosa, nem de pau, nem nenhuma outra coisa que seja". Mesma observação e mesmo espanto que o de Léry: ... única exceção a esta regra geral (a de possuir deuses, mesmos falsos $\mathrm{CRB}$ ) os tupis que, pelo que nos dizem, ignoravam o que pudesse ser uma prece ou um ofício divino e para quem se equivaliam todos os dias, tão pouco solenes uns quanto os outros. Contudo - acrescenta o autor - eles têm algum conhecimento de um deus verdadeiro, a quem chamam Tupã. Observemos aqui um primeiro desacordo: pois, quanto a esta última afirmação, é bem diferente o testemunho de Léry, a nos declarar a que foram os brancos, ele próprio e seus companheiros, que, pretextando o medo manifestado pelos tupinambás ao ouvirem o trovão - tupã pretenderam fosse este o deus de que falavam. (Hélène Clastres, Terra Sem Mal, p. 16. 
Um pouco adiante

chegaremos, com os Guarani, d̀

Terra Sem Mal, cuja busca incessante bem poderia ser o símbolo do sentido de vida deste povo.

a do devoto; "e a maior ventura que o devoto pode almejar é ver o semplante de Pay Kipara. O empenho com que se pratica o culto, dizem os índios, visa, em última instância, a obter essa graça" (15).

Afora esta divinidade mais humanizada e mais diretamente próxima dos homens do que da natureza, os outros deuses intermediários vêm do Ypáraguyà Terra. Suas visitas são percebidas por mudanças no ambiente natural, pois eis que são eles os responsáveis pelas tempestades, pelos trovóes, pelo granizo e assim por diante. Mais longe do que o lugar dos deuses intermediários, existe uma espécie de região do Alto habitada pelo povo dos "Kayowá celestes", espíritos (dos mortos? de quem?) estreitamente ligados com os seres vivos da Terra. Estes Tavyterã eram sem morada definida e desconhecem o seu próprio destino.

Um pouco adiante chegaremos, com os Guarani, à Terra Sem Mal, cuja busca incessante bem poderia ser o símbolo do sentido de vida deste povo. O seu equivalente interior, subjetivo e pessoal poderia ser a idéia de aqmjdjé: tornar-se próximo, purificar-se como o divino; no limite, chegar ao lugar do Paraíso sem passar antes pela morte.

Diversa de ser uma religiáo utilitária, centrada na relaçáo cotidianamente mensurada pela distância entre as necessidades dos humanos, o seu poder de obter dos deuses ou intermediários a proteção, e a resposta a cada caso favorável por parte deles, aos Guarani o sagrado sugere a busca de um estado de proximidade da perfeiçáo, que mais a aproxima das religióes de purificaçāo do que de outras religiōes tribais. Os deuses e, mais do que todos, Pay Kawrá são, como os humanos, pessoas corpóreas, vivas e actantes, ainda que seus corpos sejam incorruptíveis e seus atos perfeitos, ou pelo menos próximos da perfeição. Esta similitude não apenas de aspectos, mas de destinos e relaçōes sugere aos humanos serem como os deuses, nấo em poder - porque justamente esta distância estabelece a realidade das duas naturezas - mas em perfeiçăo interior. Veremos adiante em que e como este sistema de crenças, tomado a partir de um exemplo de uma das tribos Guarani representa alguma mescla com o imaginário cristão. Mas que nada nos impeça de adiantar aqui uma conclusão de Egon Schaden e que, com diferenças de um para o outro, os estudiosos da cultura Guarani irão corroborar.

Certo é que a religiáo de todos os grupos da tribo que hoje vivem no Brasil, no Paraguai e na Argentina não cristá, mas a Guarani. De tudo o que de possível cristá se possa descobrir no conjunto de suas crenças, ritos e cerimônias conservaram-se

(15) Schaden, Egon, A Religiāo Guarani e o Cristianismo, p. 9.

Estudos Avançados, 4(10) 
apenas aspectos tangíveis e formais. O conteúdo é pagáo(16).

\section{A Terra Sem Mal}

Se é notório que surtos revivalistas, messiânicos e/ou milenaristas devem ser associados a situaçóes críticas de mudança, a momentos de intervenção exterior sobre o poder de decisão do destino de sociedades, classes ou etnias, então o que explica que entre os Tupi de ontem e os Guarani de agora subsistam a idéia e o desejo coletivo da busca da Terra Sem Mal? Em que e como essas tribos opóem sempre a uma religião regida pelo código do xamã, onde o sistema Guarani se confundiria com o de outro qualquer grupo tribal da América Latina, uma religiáo regida pelo código do profeta, do Karaí, o pregador incansável de uma Terra até hoje não encontrada? Pois - e esta é a questão que importaria considerar aqui - tanto os antigos Tupinambá quanto os diversos sub-grupos Guarani dos primeiros anos da Conquista e, por certo, de muitos anos antes dela, desenvolveram uma religião fundada sobre a esperança de uma busca da Terra Sem Mal. Teriam estabelecido isto no tempo em que, no Litoral do Brasil ou nas matas do Chaco paraguaio, eram senhores de povos e terras, índios guerreiros dominadores jamais subjugados até à chegada dos europeus. Viveram errantes a sua busca por mais de $\mathbf{5 0 0}$ anos; vivem o seu presságio ainda hoje. Deixo a palavra com Alfred Metraux.

Os missionários que viveram, nos séculos XVI e XVII, entre os tupinambás do litoral brasileiro,

(16) Schaden, Egon, A Religiāo Guarani e o Cristianismo, p. 5. Năo custa transcrever aqui a síntese feita por León Cadogan a respeito do sistema religioso dos Mbuá, da regiāo de Paso Yoguai, a leste do Paraguai. Ela estende a descrição resumida a partir de Schaden e as duas juntas podem ser tomadas como uma referência segura ao que seria, em princípio, a "crença Guarani" hoje.

Por meio da profunda meditaçăo, Ñamandú Ru Papa Tenond criou o rocio primevo, o seu próprio corpo. De uma parte íntima de sua sabedoria criou o Ayvú Rapytá, " sede da fala" ou origem das almas. Criou também o Mborayú Rapytá, a fonte do amor ao próximo. Depois criou o Mbré-Aña Rapitã, a fonte do cântico sagrado. Méditou sobre quem deveria ser partícipe das palavras de seu cântico. Criou então os primeiros deuses (ou chefes dos deuses), os "que não têm umbigo", cada qual estirpe de numeroso povo celeste, e deu-lhe a consciência da divindade. Criou a Ňamandú Pyg ataci ( Namandu de Grande Coraçāo), a Karal Ru Etê, "Verdadeiro Pai do Karaí" que é deus do fogo e mora a leste; criou a Djaky Ra Ru Etê, "Verdadeiro Pai dos Djakairán, o deus da neblina e primavera, que mora ao norte; criou Tupá Ru Etế, "Verdadeiro Pai dos Tupã", o deus da chuva (ou das trovoadas?), que mora a oeste. Cada um dos povos celestes por eles governados tem as suas próprias tarefas. Cuidam das estaçōes do ano, do tempo, do crescimento das plantas. Todo chefe de um povo celeste é também Nee $R u$ Etế, "verdadeiro pai das almas", e cada ser humano é afim a um deles. Namandu Rú Papá Tenondé criou os sete paraisos do céu, criou o firmamento, que repousa sobre quatro esteios, $\gamma_{p y}$-ráif e a Primeira Terra, fazendo-a descansar sobre uma coluna de madeira. A "Primeira Terra" foi vítima de um dilúvio que a inundou por causa de um incesto. A "Terra Nova" em que vivemos, foi criada por Nanderí Papá Miri. Também ela poderia ser destruida (Egon Schaden, Religiắo Guarani c Cristianismo, p. 10). 
Teria uma terra

desejada sido

antes e por muito

tempo um local

terreno proximo, apenas livre da opressão da Colônia? falam, reiteradamente, na influência exercida sobre esses borígenes pelas profecias de certos xamãs (melhor seria dizer, karai - CRB) e pelas perspectivas de uma era áurea, anunciada para muito próximo. Pormenores, freqüentemente obscuros, fornecidos a respeito do assunto pelos antigos cronistas, tornam-se mais compreensíveis quando os comparamos aos acontecimentos, relativamente recentes, que se produziram no seio de alguns grupos guaranis do paraguai e do sul do Brasil... É a Nimuendaju que cabe o mérito de ter iniciado as primeiras pesquisas metódicas nesse domínio. O referido sábio encontrou, em 1912, em litoral perto de São Paulo, um pequeno bando de índios guaranis vindos do Paraguai. Eram alguns sobreviventes do numeroso grupo que se pusera em marcha em busca, além-oceano, da "terra onde ninguém morria". A leva constituia a última vaga do vasto movimento migratório de origem religiosa que, começando em 1810, se prolongara até os começos do século XX. Três tribos tinham tomado parte do movimento - os apapocuva, os tanhiguás e os oguauívas, todas, outrora, habitantes do sul de Mato Grosso, nas fronteiras paraguaias(17).

A Terra sem Males não é apenas um lugar para onde a tribo deve se deslocar sem tréguas em busca de uma vida sem a morte e sem o mal. Ela é também um tempo, pois eis que pelo menos entre os Guarani atuais um cataclismo próximo que, diferente de um primeiro, ancestral, destruirá a Terra má de agora e somente seráo salvos os que houverem se posto em marcha em busca da Terra Sem Mal. Aqui em nada a simbologia religiosa dos profetas guarani difere da de outros movimentos messiânicos ou milenaristas, em que o movimento e o lugar de salvação não são dados pela vinda de uma divindade ao grupo, mas por meio de uma viagem do grupo a um lugar sagrado, terra da salvação(18).

(17) Ver Metraux, Alfred, A Religiño dos Tupinamba, p. 176.

(18) O Mito da destruiçāo da Primeira Terra prenuncia a destruiçăo da Segunda Terra, a atual, o que torna a busca da Terra Sem Mal não apenas uma promessa de encontro possível de um mundo perfeito, a começar pela ausência da morte, como também a alternativa única de o povo Guarani espacar da segunda destruição. Após sintetizar a descriçăo do extermínio dos homens da Primeira Terra, Alfred Metraux conclui da seguinte maneira, seguindo dados obtidos por Kurt Nimuendajú:

O cataclismo que já uma vez aniquilou o universo não é o último a ameaçar o mundo, cujo fim, aliás, está próximo. Quando este acontecimento se produzir, o criador enviará o morcego Mbont recoypy que devorará o sol, soltando o tigre azul, animal semelhante a um căo. $O$ tigre azul destruirá impiedosamente a raça humana. Em seguida virão o fogo e a água (Metraux, Alfred, $A$ Religiño dos Tupinambá,p. 177). 
Os guaranis modernos vivem persuadidos da próxima destruiçáo da terra, considerando toda a catástrofe de que se tem notícia, como signo prenunciador do desastre. Quando os sonhos, visóes ou simples fenômenos naturais insólitos fazem pressentir a algum feiticeiro a aproximaçăo do perigo, este, seguindo o exemplo de Guyraypo, procura escapar-se-lhe, reunindo em torno de si e sob sua direçáo os mancebos, que se entregam ao jejum e à dança; todo um ano consagrado à dança mal chega para velar a orientaçăo ou caminho a seguir(19).

Yvy Mará Ey, a Terra Sem Mal, Terra Sem Males, também dita, como em Egon Schaden, $\Upsilon_{\nu y}$ Nombimbyre, Terra Escondida, $\Upsilon_{\nu y} K a t u$, a Terra Boa que León Cadogan ouviu dos Mbuá no Paraguai, um lugar longe, para além de Kurutut Retã, a Terra dos Portugueses, para além do Mar Grande(20).

Teria havido aqui uma variação de sentidos na qualificação deste lugar cuja própria direçáo sempre foi um problema para os índios Guarani? Teria uma terra desejada sido antes e por muito tempo um local terreno próximo, apenas livre da opressão da Colônia? Ora, se de uma lado antropólogos como Hélène Clastres defendem que as migraçóes Guarani em busca da Terra Sem Mal teráo sido antecedentes à chegada dos portugueses e espanhóis e, como vimos, teráo encontrado os Guarani livres de opressóes de outras tribos vizinhas ou de privaçóes da natureza, pelo menos Bartolomeu Meliá chama a atenção para o fato de que nos escritos do jesuita Montoya, uma primeira $\Upsilon_{\nu y}$ Maraney surge como terra virgem, ainda não tocada;" sol intacto, que náo foi ainda edificado" e se confunde com kaa maraney: monte de onde naio foram tirados os paus. Ao contrário do motivadíssimo sentido sagrado que os Guarani posteriormente dariam à $\Upsilon_{\nu y}$ Mară Ey, teriam os seus primeiros significados feitos apenas alusáo à busca, mais ecológica do que religiosa, de territórios virgens de caça e prática da agricultura indígena?

(19) Metraux, Alfred, A Religiăo dos Tupinambá, p. 177. Um exemplo de como isto acontece é assim descrito por Egon Schaden. Em 1949, quando trabalhei entre os Kaiowá de Panambi, perto de Dourados, os índios da aldeia estavam em alvoroço por causa da decisáo do Governo de fundar uma colônia agrícola em seu território. Achavam que o fim do mundo estava próximo, eo próprio sacerdote do grupo promovia danças religiosas para precipitar o evento (Schaden, Egon, Religiăo Guarani e Cristianismo, p. 15).

(20) Ver Schaden, Egon, El" Modo de ser Guarani on la Primera documentación Jesuitica,p. 5-17. 
... a perfeição de si mesmo através do domínio do rito da palavra e da dança e através do controle ascético do corpo e do espírito...
$\mathrm{Na}$ busca de um solo onde pudessem viver o seu modo de ser autêntico, os Guarani podem ter feito cristalizar tanto suas antigas aspiraçōes religiosas como a consciência de novos conflitos históricos. Ypy maraney se convertia numa "terra sem mal", terra física como em sua concepçáo antiga $\mathrm{e}$, ao mesmo tempo, terra mística depois de tanta migração frustrada(21).

Seria esta Terra Sem Males, seria a vocação persistente de sua busca, seria esta obsessão de um Paraiso na Terra, mas para além năo apenas do mar, mas até da morte, o núcleo verdadeiro da religiáo de um povo disperso entre tantos sub-grupos, por tanto tempo?

\section{Tradição e Mudança: Resistência e Integração}

A que lugares e sentidos geográficos e simbólicos conduzia e conduz a religiāo dos Guarani? Nem todos os estudiosos da questão concordam com as conclusóes de Hélène Clastres, algumas delas já nossas conhecidas, outras a serem re-discutidas a seguir. Não são poucos os que avaliam como quase delimitantes as suas conclusóes, mais eis que nela temos um intrigante ponto de partida. Noemi Dias Martinez propóe uma leitura etno-histórica que possibilite uma outra compreensão do nomadismo secular desses índios que, encontrados já muito dispersos entre territórios tão distantes, à época da conquista, foram vistos ainda em viagens ou sonhos de viagens no final do século passado, no princípio deste e mesmo nos últimos anos(22). Ela aceita a interpretaçáo dada pelo padre Montoya em 1640 e aqui já apresentada a partir de Meliá: Yvy Maraney, a Terra Sem Mal, na verdade, é o lugar do solo intacto, o espaço ainda não edificado, não transformado pela mão do homem de terra da natureza em local de cultura. Ca Maraneyé o nome dado ao monte de que ainda não foi tirada a madeira e que náo foi, igualmente, trabalhado. É a floresta, o lugar ancestral de uma tribo de caçadores, pescadores e coletores(23).

Como praticamente todos os outros estudiosos dessa religiăo de índios ascetas, conduzidos por seus Karai, profetas, senhores das" belas palavras", sabedores dos cantos e danças cujo sentido, decifrado, náo faz mais do que indicar à tribo o lugar e a direçáo da terra buscada, Noemi Diaz deverá ressaltar que um dos traços mais notáveis da

(21) Meliá, Bartolomé, Religiāo Guarani e Cristianismo, p. 16. Ver também o texto de León Cadogã: Aymí Rapyta - textos míticos de Mbyá-Guarani Del Guaira,p. 144-5.

(22) Diaz, Noemi Martinez, La Migration Mbya (Guarani),p. 148-69.

(23) Id.Ibid. p. 164.

Estudos AvançAdos, 4(10) 
cultura Guarani é a sua resistência a modificaçōes fundamentais dos sistemas de símbolos e códigos que organizam o modo de ser tribal "dos antigos".

Qualquer que seja a interpretaçáo dada ao lugar da $\Upsilon_{\nu y}$ Maraney por sucessivos profetas, ela é sempre em direção a Leste, ao mar, ao litoral atlântico do Brasil(24). A um lugar, quem sabe? Situado mesmo do outro lado do oceano(25). Um lugar, portanto, terreno, concreto, possivelmente conhecido dos ancéstrais: a floresta em geral ou, então, alguma regiāo definida de matas intocadas, não conhecida $\mathrm{e}$, por isto mesmo, não dominada pelo homem branco. A Terra Sem Mal é o espaço do retorno à possibilidade, dada pela natureza e reencontrada pelo exercício persistente do nomadismo, da reproduçáo de um modo de vida de uma tribo que mesmo depois de reduzida à Missáo e subordinada ao trabalho agrícola, jamais deixou de pensar-se como de caçadores, para quem a atividade agrícola é, ela sim, desqualificadora e complementar. Que outro lugar realiza isto melhor do que a floresta atlântica, terra dos Tupi dos tempos da Conquista?(26).

Menos terrenamente utilitários e geográficos, os Guarani que Egon Schaden interpreta na mesma direçáo de Hélène Clastres buscam através de uma viagem - solidária e ascética, tribal e nômade atingir ao mesmo tempo o Kandire, a perfeiçáo de si mesmo através do domínio do rito da palavra e da dança e através do controle ascético do corpo e do espírito, e $\Upsilon_{p y}$ Maraney, o lugar paraíso insento do mal. E atingi-los ambos, um através do outro, aqui mesmo, antes de passar pela experiência da morte, antes de dissolver-se no mal sem retorno(27).

Mas é o mesmo Schaden quem retorna a Bartolomé Meliá e ao Tesoro do padre Montoya para lembrar uma primeira possível transformação

(24) IdIlbid. p. 150.

(25) Getulio Vargas savait que de l'autre coté ils arriveraient à Lisbone. Devant leur insistence, Vargas permit leur embarquement sur un navire... qui arrivà à Bahia. Durant un séminaire sur les Guarani, à IUniversité de São Paulo, le professeur SCHADEN indica (..) qu'en 1934 Getulio Vargas envoya les indiens à Espirito Santo, mas en realité les indiens voulaient travesser LAtlantique. Diaz, Noemi Martinez, La Migration Mbya (Guarani),p. 154.

(26) Assim: "que bien que les Mbya réalisent des travaux agricoles et en mentionent les techniques dans leurs mythes, ils ne se considèrent pas comme des agriculteurssédentaires mais comme des chasseurs cueilleurs essentiellement. En dautres termes, le processus de transformacion du nomadisme Guarani presente une fréquence déterminé par les forms idéologiques-politiques. Diaz, Noemi Martinez, La Migration Mbya (Guarani),p. 167.

(27) Schaden, Egon, Religiāo Guarani e Cristianismo, p. 10. Também em Schaden e de acordo com o depoimento de León Cadogan, a $\Upsilon_{y y}$ Marucy, $\Upsilon_{y y}$ Mara Ey estaria situada "para além dos portugueses", isto é, para além da terra dominada pela empresa da Conquista, p. 16-7. 
Nāo ha uma

cidade celestial a

construir ou a

encontrar alhures;

há um lugar $a$

descobrir através

da ascese

individual

(Kandire) $e$ coletiva..

de sentidos na busca da Terra Sem Mal. Índios caçadores, o primeiro significado dado ao lugar da busca nômade é mesmo a terra intocada, própria a uma tribo que vive e deseja viver livre da agricultura e de seu modo de vida sedentário. Nisto, como também Noemi Dias Martinez acentua, os Guarani em nada se diferenciam de outras tantas tribos e naçóes de índios nômades, caçadores das florestas da América do Sul. Sómente depois de submetidos ao poder colonial da Conquista, conduzidos contra a vontade à redufáio ou à encomenda, é que os Guarani transformam um lugar conhecido da natureza - a floresta em um local desejado da religião: uma terra desconhecida, mas simbolicamente real além de tudo e, mais do que tudo, dos poderes da presença maléfica dos homens brancos. Assim, a terra sem brancos, lugar ancestral de caça, passa a ser o lugar místico da negaçáo de todos os males, a começar pelo mal da morte(28).

A começar pela própria sociedade, insiste Hélène Clastres. Pois o que pregavam os Carat, Karai, profetas errantes de tribo em tribo, de aldeia em aldeia, sujeitos de um poder religioso absolutamente inquestionado, até quando os seus ouvintes e seguidores os

descobrissem mentirosos ou iludidos, era a busca de um espaço de vida coletiva sem um local e sem lugares demarcados onde fossem abolidas não as regras dos costumes do modo de vida dos antigos, mas as relaçóes da vida social que negassem a sua ancestral naturalidade. $O$ lugar de um tempo sem as etapas da história, onde fossem abolidas ela própria e a sucessáo das geraçóes de homens.

Com tantos outros lugares de paraiso, na sua face mais externa a Terra Sem Mal é o lugar da absoluta abastança num tempo de realizaçáo plena do desejo de um povo de caçadores: "o milho cresce sozinho, as flechas alcançam espontaneamente a caça... Opulência e lazeres infinitos. Mas nenhum trabalho, portanto, danças e bebedeiras podem ser as ocupaçóes exclusivas" (29). Mas se em tal Terra os princípios éticos, lúdicos e religiosos do ñandé renkodevem ser preservados e retraduzidos para a eternidade de uma vida opulenta, as normas antigas de orientação da vida social antecedente devem ser abolidas, a começar pelas próprias regras do casamento. Do que elas valeráo, se não haverá mais geraçóes? O que elas poderão valer, ali, onde foram abolidos o trabalho, o poder, a submissáo e o conflito que deles decorrem? "Dêem suas filhas a quem vocês quiserem" diziam os carat. O que traduz sem dúvida a recusa das duas prescriçóes essenciais dos tupis, a do primo cruzado e a do tio materno, mas - mais

(28) Schaden, Egon, Religiano Guarani c Cristianismo, p. 16-7.

(29) Clastres, Hélène, Tara Som Mal,p. 67.

Estudos Avançados, 4(10) 
profundamente - a recusa de toda a proibição: pois, se tudo é permitido, nenhuma união é incestuosa" (30).

E Hélène Clastres conclui:

Quer dizer que o mal - trabalho, lei - éa sociedade. A ausência do mal - a terra sem mal - é a contra-ordem. Não é por acaso que as únicas atividades sociais destinadas a se manterem na Terra Sem Mal são as festas de bebidas: essas festas são também, na sociedade, a expressáo da contra-ordem (ao mesmo tempo, sem dúvida, que são o meio de controlá-la). Finalmente, a Terra Sem Mal é o lugar da imortalidade, enquanto nessa terra os homens nascem e morrem: como se tal fosse a correspondência entre a ordem social das regras (que implica troca matrimonial, trabalho, etc.) e a ordem natural da geração (que implica nascimento e morte) que bastasse para abolir aquela para se libertar desta. $O$ homem nasce bom (nasce para deus), a sociedade deprava-o (abole sua natureza divina): poderia ser este o axioma da antropologia dos tupis, ou do que se poderia chamar sua antropodicéia(31).

Rousseau por certo gostaria de haver nascido tupi-guarani. Vejamos bem: a procura sem fim de uma Terra Sem Mal é a recusa ativa da sociedade, de sua vida em seu estado negador da natureza e daquilo a que - mesmo antes da vida dos brancos e da Conquista, ela obriga os homens a serem e viverem. E se fracassam as migraçōes de tantos povos, através de tantos anos, é porque o seu projeto: dissolver a sociedade, é em si mesmo suicida(32).

(30) Id.Ibid. p. 67.

(31) Id.Ibid. p. 68.

(32) Hélène Clastres procura definir o Kandire: "O que eles se esforçam por pensar é que, entre a existência finita que é a dos humanos na yoy mbacmegua (= terra má) imperfeita porque prometida a uma destruição a uma destruição próxima e a vida sem fim desfrutada pelos divinos na yry maracy (= terra sem mal), năo existe ruptura. E possível passar de uma à outra sem solução de continuidade; ou, como dizem os próprios mbiás sem passar pela prova da morte: oñemokandire. Essa expressão que, segundo a etimologia fornecida por León Cadogan, significa literalmente fazer com que os ossos permaneçam frescos a mesma que os mbiás empregam para significar a chegada à Terra Sem Mal sem perder sua narureza, sua forma humana, isto é, sua postura vertical. Sem sofrer, portanto, a prova da morte (íntegro de corpo e alma, por assim dizer), pois a verticalidade define o ser animado. Que o conceito de Kandire traduza a possibilidade de alguém continuar vivo e - ao mesmo tempo - tornar-se imortal não aparece apenas na etmologia da palavra e na sua explicação pelos mbiás, mas também no uso que os mitos fazem dela, (id.ibid, p. 89). 
Para além da sociedade terrena o homem guarani deixa, ele mesmo, de ser um homem regido por sua deficiência. Retornado ao estado de natureza que o aproxima do momento antecedente à própria criaçăo, ei-lo que, tal como antes os seus Karat, torna-se como os deuses. Seu caminho? Destruir não apenas a sociedade que obriga o homem a ser servo do próprio homem - de si mesmo - mas também a cultura, ou melhor, o que há nela de propriamente humano, logo, de socialmente produzido por ele: por coerção e sob coerção. Não há uma "cidade celestial" a construir ou a encontrar alhures; há um lugar a descobrir através da ascese individual (Kandire) e coletiva, a viagem da tribo onde a vida de homens próximos a deuses possa ser coletiva - como a deles - sem ser social.

Se uma tal interpretação é verdadeira, eis que podemos crer com Hélène Clastres que estamos diante de um movimento de busca tribal de um lugar de deuses para a vida do homem que em nada se confunde com os messianismos e milenarismos costumeiros da América e, com mais ênfase e persistente atualidade, do Brasil(33).

Porque năo havia, pelo menos antes da chegada dos europeus colonizadores, o projeto comum da "sobrevivência de uma sociedade ameaçada por outra na sua própria existência". E nisso:

O profetismo tupi é exatamente o inverso de um messianismo: nasce de uma cultura que segrega por si mesmo seu próprio questionamento e na qual a religião, por ser o lugar dessa crítica, gera a dispersão. As migraçóes para a Terra Sem Mal ilustram dessa maneira uma das possíveis saídas para a crise - manifestada pelas tendências inconciliáveis do religioso e do político - das sociedades tupis-guaranis: a autodestruiçáo dessas sociedades(34).

"Os ritos religiosos dós guarani são, portanto, governados pela crença que o homem pode alcançar o Kandire, pode ascender à imortalidade sem passar pela prova da morte" (Id.Ibid., p. 92). Chegar à vida plena sem passar pela experiência da morte, chegar ao Kandire, implica a dupla viagem, como vimos: a do indivíduo através da ascese e a da tribo através da busca da Terra Sem Mal. É uma promessa dada ao Guarani, mas uma promessa somente cumprida por meio de um esforço que, nos dois sentidos, implica o abandono de tudo e uma busca incessante.

(33) Recomendo ao leitor dois estudos a respeito do profetismo indígena na América Latina. Estäo ambos publicados em italiano em: LAmerica Rifondata - analisi di tre risposte indigene alloccidente. $O$ primeiro é justamente ainda sobre os Guarani e foi escrito pela antropóloga Cristina Pompa: Il Mito della "Terra Senza Mal" e; o segundo de Gilberto Mazzoleni, é: Huave - la rifondazione quale constante.

(34) Clastres, Hélène, Terra Sem Mal,p. 68. "O Breve relato dessas migraçōes dos guaranis para a Terra Sem Mal basta para mostrar, também aí, a originalidade de uma tradição religiosa que nem os maiores abalos conseguiram enfraquecer. Nenhum sincretismo 
Estamos assim diante de uma dupla interpretação negadora do messianismo clássico como fundamento da religiáo, do ethos e da busca de destino dos Guarani. De um lado as teorias utilitárias que reduzem a busca da Terra Sem Mal à procura terrena de um lugar de natureza, realizado na e como a floresta virgem: lugar aquém da cultura, terra dos ancestrais, da reprodução sem fim do modo de ser do caçador guarani. De outro as teorias que definem essa mesma busca como sendo regida em sua essência por um simbolismo religioso que desloca para a imaterialidade de um viver para além da cultura, logo, para um estado de natureza próprio dos deuses, o lugar da vida que o coraçáo do homem e os desejos da tribo devem querer procurar sem tréguas. Em ambas as interpretações não se espera a vinda de um redentor, de um guia, de um ser supremo que destrua "este mundo" e o seu mal, deixando a salvo apenas uma fraçáo devota de seguidores fervorosos. De uma parte eis o ideal de volta a um lugar na Terra e a um modo de ser que destrua náo a cultura e a vida que ela codifica e traduz, mas aquilo que nela impede a tribo de viver a seu modo: como uma gente da floresta, aquém da agricultura, aquém do poder tornado uma forma de coerção. De outra parte, a negação pura e simples de qualquer espécie de sociedade, porque para os homens atingirem o Kandire e, imortais, tornarem-se próximos aos deuses, precisam não habitar uma outra sociedade, mas viver já para além de qualquer uma.

O discurso dos Carai sobre a Terra Sem Mal continua a ser, depois de passados cinco séculos, de um mesmo teor: uma fala religiosa sobre a sociedade presente. Ele é, ao ver de Hélène Clastres, antes de mais nada um discurso crítico sobre a sociedade com uma vocação à crítica que o passar do tempo enfraqueceu. Sendo a negaçáo de um estado de sociedade presente, em nome das "boas normas", o modo de ser dos antigos é ainda hoje a essência presente se realiza como um estado interno de relaçóes - ainda que sob o poder e a coerçáo de fatores e sujeitos externos - negador, por sua vez, de uma ética de salvação a que o profeta conclama a tribo (35).

Se um primeiro pensar religioso tupi-guarani negava a sociedade como a possibilidade da Terra Sem Mal, o pensamento guarani atual aceita

existe aqui. E, ao contrário do que se dá com os movimentos messiânicos, não deparamos com nenhuma ressonância política: năo se trata de revoltas; nenhuma reivindicação política ou territorial acompanha ou provoca as migraçōes. É, ao contrário, e como antigamente, o abandono do território e a passagem à vida nômade. Os guaranis certamente năo procuravam obter uma independência política e econômica que já possuiam: devemos recordar que os grupos que empreenderam essas migraçōes viviam num território (na fronteira entre o Brasil e o Paraguai) onde podiam desfrutar de uma autonomia real, embora precária, sem dúvida, proregidos que estavam de todo o contacto por um meio natural (a densa floresta tropical que cobre toda a regiāo) muito dificil de se penetrar e, na época, ainda virgem (op. cit, p. 81-2).

(35) Clastres, Hélène, Terra Sem Mal,p. 109. 
Isto é, pensare agir como os brancos que, submetendo-os ao seu poder econômico e politico, submetem as normas do N̄andé rekó aos seus proprios preceitos e interesses.

supor uma sociedade justa cujo modelo, a ser encontrado em algum lugar do futuro, é o de seu próprio passado. Isto porque o mal é a ambivalência e ela não é mais do que a junção de valores antigos e valores novos, onde são verdadeiros, para o Guarani, apenas os antigos, os da tradição, "os que distinguem os Poranguei dos que não foram enfeitados - os paraguaios" (36). A busca da Terra Sem Mal começa por uma ascese que não é outra senáo, vimos já, o viver de acordo com as normas tribais dos antigos. Mas se tal mal é individual e existe quando o índio é seduzido pela dessemelhança por ser, ele mesmo, Guarani e viver também como o branco - é sobretudo na vida social que o mal da dessemelhança se instala, quando nela duas culturas coexistem em conflito. Não adianta mais viajar: pois se individualmente a pessoa do Guarani não mais consegue livrar-se de ser ambivalente, também a tribo não tem mais como se livrar de converter-se subalternamente aos desígnios do mal. Isto é, pensar e agir como os brancos que, submetendo-os ao seu poder econômico e político, submetem as normas do N̄andé rekóaos seus próprios preceitos e interesses. $\mathrm{E}$ se os brancos são o mal porque não "foram enfeitados", porque desconhecem "as belas palavras, porque náo sabem conduzir o canto e a dança que trás a fala dos deuses ao coração dos humanos, os Guarani tornam-se maus porque não sabem mais como não mesclar os símbolos de seu modo de ser como os dos brancos.

Nós, os nbanderus de hoje, fazemos apenas esforços esporádicos para cantar, e fadados ao fracasso. E como poderíamos cantar? Veja: uma manhã, na rede, me ponho a cantar as palavras que me sáo inspiradas pelos senhores do além. E minha mulher me interrompe: "o que está fazendo você, cantando quando não há sal nem banha para a refeição?". Tenho que me levantar e sinto raiva. Impossível cantar quando se está com raiva. Como poderíamos receber inspiraçáo quando temos que trabalhar para nossas famílias não morrerem de fome?. Precisamos trabalhar para comprar carne, porque o senhor dos taiaçus e dos outros animais da floresta os impede de cair em nossas armadilhas. E precisamos trabalhar para nos vestirmos como os paraguaios. Porque os nossos próprios companheiros chegam a zombar dos ornamentos rituais(37).

(36) Id.Ibid. pg. 109-10.

(37) Leon Cadogan, apud Clastres, Hélène, Torra Sem Mal, p. 111.

Estudos Avançados, 4(10) 
Eis um caso surpreendente de uma religiăo indígena que resiste a deixar-se integrar no corpo de valores de outras religiōes. Que persiste como pode em manter viva a palavra do profeta, dirigida agora àquilo que foi, em um passado da tribo, apenas a condiçáo inicial para a busca da vocaçáo do Guarani: a Terra Sem Mal. Já que a comunidade dos índios guarani náo é mais a dos eleitos - e os fatos da vida submetida o demonstram, com evidência, que eles pelo menos, saibam entre os outros vivem como os eleitos. E justamente porque a própria vida nega agora, sujeita e ambígua, até mesmo uma tal possibilidade, ainda que a cultura guarani possa se ver repetindo as palavras e os gestos rituais dos antepassados, isto somente serve a tornar patente que o sentido e a vocaçáo antigos não são mais possíveis de serem realizados. Conviver subordinadamente em uma mesma terra com os brancos implica a perda das condiçóes pessoais e coletivas de pôr-se em marcha em busca do Kandire. Por isso mesmo o discurso religioso dos Karai - e não será isto comum entre outras experiências culturais do tipo profético, messiânico ou não? - realiza um deslocamento inevitável. Ele transfere a busca real, geográfica e simbolicamente necessária de um lugar dado em visōes e sonhos como existente e à espera do único povo eleito capaz de alcançá-lo através de seu próprio esforço coletivo, para uma busca pessoal de ascese; de um retorno do coração e da conduta às normas da vida antiga, sem a mescla - na pessoa e na cultura - do mal que é o valor do branco e tudo a que ele conduz. Eis a vocação coletiva da história transformada em um desejo de ética.

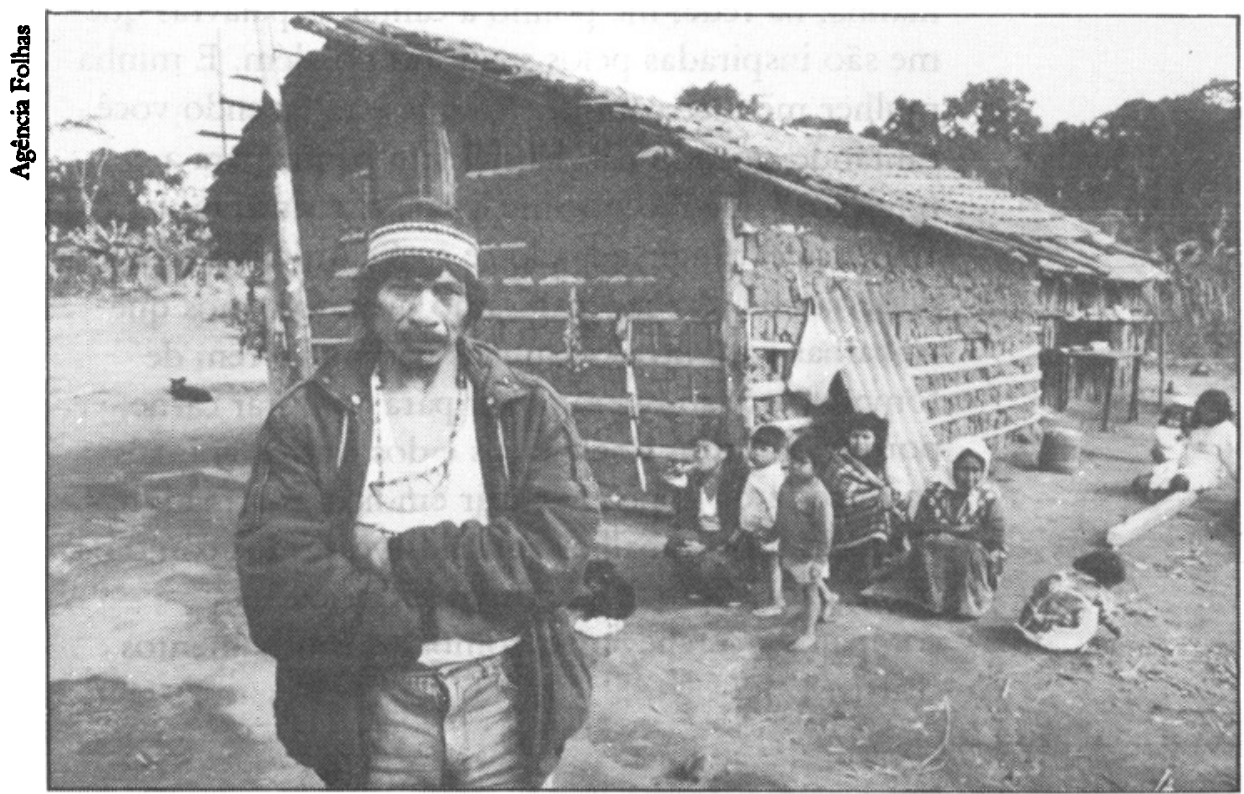

" cmoora pareça clenuncamente estranho, nāo é fácil dizer-se quantos săo os guarani de agora ..." 
Escolher um regime alimentar tem, assim, implicaçóes econômicas e sociais de monta: implica adotar uma prática econômica conforme ao ideal mbiá (sem dúvida alguma), mas náo é realidade, $\mathrm{e}$ restrita demais para ainda ser possível. Ademais, não basta um comportamento econômico conservador: a ascese alimentar não dá a perfeição, mas somente o que a torna possível - o mborayu - Para obter o aquyje, é preciso além no conservantismo (ou na recusa da sociedade atual): cumprir um ritual (ou seja, algo que em princípio deveria envolver o conjunto da comunidade) ao qual a comunidade já renunciou há muito tempo. Restrição no plano enconômico, excesso a nível da vida ritual: vale dizer que a Terra Sem Mal só é acessível ao preço de uma opçáo duas vezes impossível, pois convida todos a se conformarem a modelos culturais que náo são mais os dos mbiás. $O$ discurso religioso evidentemente não mudou sozinho, a prática religiosa também se modificou: ainda é possível dançar e rezar, mas não é mais possível - exceto sendo um louco - repetir hoje os gestos dos antigos caraí e abandonar tudo, à procura da Terra Sem Mal(38).

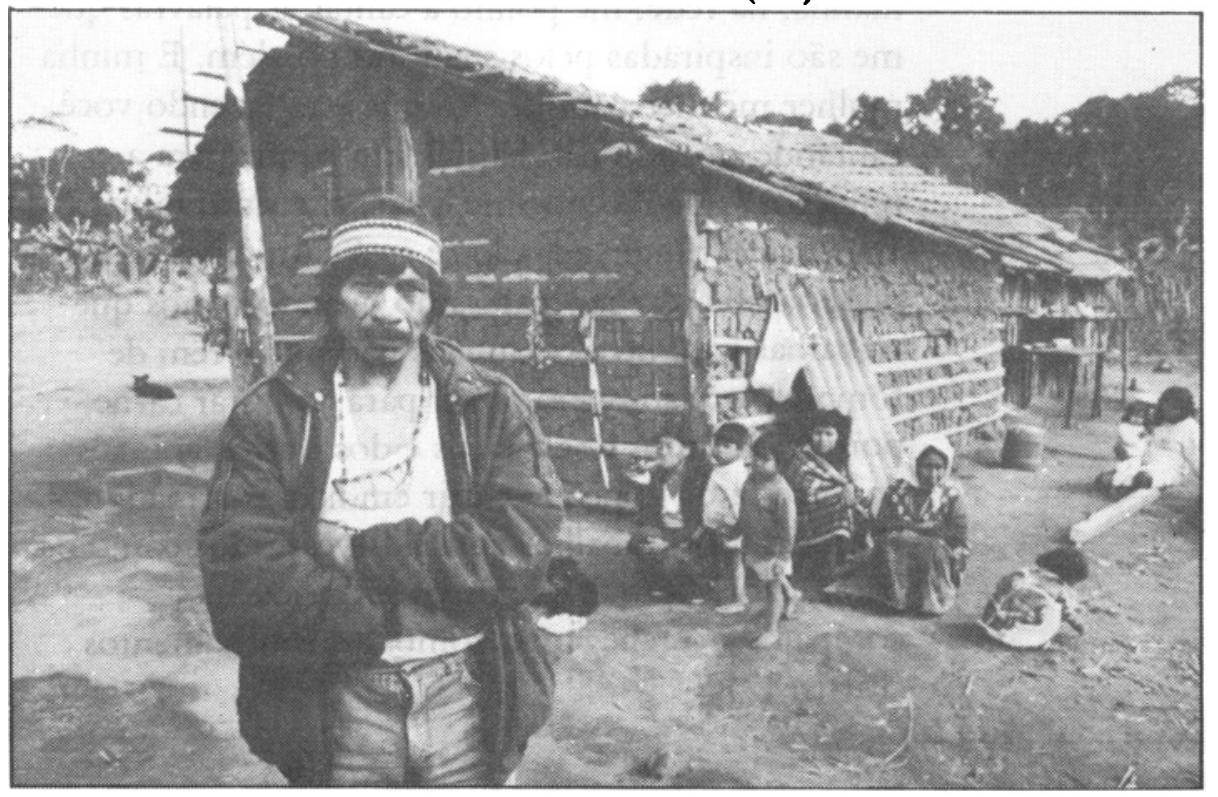
"Os poucos guarani foram no passado e são atualmente submetidos ao trabalho tutelar e
conservacionista de missóes cristās"

(38) Clastres, Hélène, Terra Sem Mal,p. 110. 
Assim como em outras interpretaçōes indígenas, primeiro o nomadismo guarani buscaria apenas o lugar geográfico real da floresta, a terra da caça abundante livre dos brancos, o território ancestral dos antepassados e, depois, reconhecida a impossibilidade de tais deslocamentos livres em um mundo denominado pela presença coerciva do homem branco, desloca tal espaço natural e social de busca para um plano etéreo de realização religiosa, fora ou além dos limites do mundo terreno pelo menos próximo e conhecido. Em um terceiro momento há um novo deslocamento: a procura de uma terra fora do mundo e da sociedade (um espaço sem lugares marcados, onde se abolem as relaçóes sociais em um tempo sem pontos de referências, em que se abolem as geraçóes), a uma busca interior do retorno ascético ao modo de ser dos antigos, ainda que isto tenha que ser feito aqui mesmo, entre os brancos e sob o seu poder. Ou por isto mesmo. $\mathrm{O}$ imaginário profético guarani repete outros: o paraiso existe aqui, fora do poder opressor do outro e da lógica do outro impressa na cultura da tribo; o paraíso existe além do mundo que o outro domina; o paraiso não existe a não ser no interior, dentro do coraçăo do homem subjugado, que se livra sem fazer-se ser libertado.

O que o profetismo guarani anuncia já não é mais a possibilidade de a tribo atingir uma terra perfeita onde o homem guarani escaparia do mal e da morte, mas sim a destruiçáo próxima, através do mal e da morte, de toda a terra, isto é, de todas as sociedades. Há agora entre o homem guarani e seus deuses uma distância impossível de ser vencida. Náo porque os deuses se calaram, mas porque os humanos, dessemelhantes, ambivalentes, não sabem mais ouvir as suas palavras. Não sabem mais, portanto, pronunciá-las.

Nós, que somos as últimas geraçóes já não nos abstemos de mais nada de agora em diante náo sabemos mais conduzir-nos.

\section{Religião Guarani e Cristianismo}

Depois de submetidos à Colônia, os povos Guarani aprenderam com os brancos a se dividirem a si próprios em indios das missóes, civilizados, e indios da floresta, selvagens. Sabemos que muitos anos mais tarde esta mesma oposição rege auto-classificaçōes dos Guarani. A própria diferença entre índios integrados, vivendo próximos às cidades do Brasil, da Argentina, da Bolívia e Paraguai, e índios livres, habitantes ainda das últimas florestas, como os Guayaki, não reduzidos às fronteiras de reservas, atualiza aquela primeira oposição.

Os povos guarani foram no passado e são atualmente submetidos ao trabalho tutelar e conversionista de missóes cristás. Por muito tempo, 
Outros tomaram desde então 0 caminho da vida errante e livre nas florestas. Por isto mesmo, foram aqueles que preservaram até agora mais livres de elementos brancos e cristãos a sua cultura e a sua religião. durante e após os padres jesuítas, elas foram exclusiva ou predominantemente católicas. Hoje em dia missóes evangélicas e, dentre elas, com muito mais ênfase e melhores resultados, as de grupos e igrejas pentecostais, disputam com as ordens de missionários católicos o direito e o suposto dever cristão de converter pessoas e culturas indígenas à sua fé.

Índios que nas reduçōes dos Sete Povos aprenderam os princípios do cristianismo, submetendo-se aos preceitos de uma vida sedentária $\mathrm{e}$ regida pelo trabalho agrícola e artesanal, e que encantaram os senhores do Reino com a qualidade de seus objetos de arte e de suas vozes, re-educadas para os corais das igrejas, preservam no entanto até hoje e adaptam a novas condiçóes uma cultura religiosa tribal que aos estudiosos dos Guarani espanta em um duplo sentido. Primeiro em razáo de sua própria persistência que, para além de uma simples estratégia cultural de resistência relativa a uma plena integraçáo a sistemas simbólicos impostos, parece traduzir uma rara vocaçáo de fidelidade indígena à sua própria religião. Em segundo lugar, em razão da maneira como, guardadas as diferenças de integração cultural entre sub-grupos e aldeias, subsiste entre os Guarani uma notável homogeneidade religiosa, inclusive na lógica das atualizações agora inevitáveis.

Náo sáo poucos os pesquisadores da cultura guarani que aceitam a idéia de que, mais do que entre outros grupos tribais das Américas, uma declarada conversão de pessoas, famílias e mesmo aldeias a algum dos ramos do cristianismo, tem apenas facilitado a possibilidade de preservação do sistema de crenças e cultos essenciais da "religiāo dos antigos", fundamento, vimos, do Nandé rekóque traça o próprio perfil de uma identidade Guarani.

Quanto às mudanças do sistema cultural, encontramos toda - a escala de variaçáo. Alguns grupos mantiveram no essencial o seu antigo modo de vida. Outros foram já levados à beira da desintegração. Muitas mudanças que se observam no sistema religioso data do tempo das reduçóes, outras se devem a influências de época mais ou menos recente. De modo geral, a cultura guarani revela resistência aos efeitos das diferentes situaçóes de contacto. Sobretudo o carácter fundamental da religiño se mostra particularmente imune ao contacto com representantes do mundo cristão. Por muito tempo, ali, a adoçáo de elementos do cristianismo não decorreu de um real confronto de dois sistemas 
religiosos, mas reflete uma estratégia para melhor conservar as crenças e os valores tradicionais. É uma forma de conceder para não ceder(39).

Frente à presença de vários grupos missionários cristãos ao redor ou dentro de uma mesma aldeia, a maioria dos Guarani em situaçáo de contacto constante com os brancos aceita identificar-se como cristá. Assim, as aldeias dos Guarani ao longo do litoral de São Paulo, no Brasil, aprendem a dividir-se simbolicamente em catolicos e crentes (isto $\varepsilon$, convertidos a alguma denominação evangélica, via de regra, pentecostal)(40). Um desdobramento, aí sim estratégico, permite à lógica religiosa indígena reconhecer, para dentro da tribo e para as interaçóes com os regionais, uma religiāo guarani de que $o$ índio se reconhece sendo, e uma adesão ao cristianismo, cuja religiăo, ao contrário, ele se reconhece tendo.

Após século e meio de submissão às missões jesuíticas, dois parecem ser os destinos tomados pelos povos guarani. Alguns deixaram-se submeter à açáo missionária dos outros grupos religiosos católicos entre meados do século $18 \mathrm{e}$ fins do século 19. Aproximaram-se das cidades e do modo de vida dos brancos e, mesclados aos seus códigos de crença, culto e identidade, incorporaram à religiáo guarani elementos míticos e mesmo éticos de um cristianismo inicialmente catequético e, depois, francamente popularizado, como o dos camponeses da Argentina, Brasil, Bolívia e, principalmente, do Paraguai, com quem os Guarani estreitaram relaçóes de troca de serviços e sentidos religiosos. Outros tomaram desde entáo o caminho da vida errante e livre nas florestas. Por isto mesmo, foram aqueles que preservaram até agora mais livres de elementos brancos e cristãos a sua cultura e a sua religiāo. Por causa desta oposiçáo de destino, sincretismos religiosos e integraçōes de símbolos cristãos à religiấo guarani variam intensamente no tecido de um núcleo religioso indígena comum. Não será outra a razão pela qual, enquanto Kurt Niemundajú nega a subsistência do cristianismo como um sistema religioso entre os Apapocúva, do Brasil, que ele descobre e descreve no começo do presente século, ressaltando na religiăo dos índios não mais nem menos do que raros fragmentos cristãos, como a existência da cruz em alguns ritos e lugares, o uso do batismo, a adoçáo do caixão cristão para a viagem final do corpo dos mortos e a representação de heróis da tribo através de esculturas de madeira, os dados de León Cadogan sobre os Mbüá-Guarani do Paraguai quase poderiam evocar a evidência, no sistema tribal de mitos cosmogônicos:

(39) Schaden, Egon, Religito Guarani c Cristianismo, p. 2, grifos meus

(40) Cherobim, Mauro, Os Indios Guarani do Litoral do Estado de Saío Paulo, p. 123-4. 
de personagens e heróis indígenas dentro de uma estrutura de acontecimentos e significados em tudo cristã(41).

Seja entre culturas indígenas francamente cristianizadas, seja entre índios escapados ao longo dos séculos de um trabalho missionário persistente, o que os estudiosos dos índios do Sul encontram, parece ser sempre uma estrutura simbólica e uma vida religiosa coletiva sem dúvida alguma Guarani. Egon Schaden diz isto sem rodeios:

Certo é que a religião de todos os grupos da tribo que hoje vivem no Brasil, no Paraguaí e na Argentina não é cristá, mas a guarani. De tudo o que de possível proveniência cristá se possa descobrir no conjunto de suas crenças, ritos e cerimônias conservaram-se apenas aspectos tangíveis e formais. $O$ conteúdo é pagáo. Entre índios cujos antepassados estiveram direta ou indiretamente na órbita de influência dos missionários, ter-se-ia a expectativa de encontrar pelo menos uma mitologia sincrética em que todos os elementos bíblicos e outras reminiscências cristãs estivessem amalgamados com os relạtos autóctenes. Mas o que na realidade se registrou é um conjunto de mitos que manteve o seu genuíno carácter aborígene. Nada do que se depara na estrutura do pensamento mítico-religioso reflete a visáo do mundo que deve ter sido a dos jesuítas(42).

Um duplo deslocamento feito pela cultura de alguns sub-grupos Guarani revela a maneira como a tribo lida com a questáo religiosa. Sobretudo quando em contacto com os brancos, os índios nāo revelam um modo cotidiano de vida e mesmo os símbolos visíveis de uma identidade pessoal, familiar e de aldeia associadas à religião dos ancestrais. Ao contrário, $O$ índio tenderá a tornar proclamada a sua

(41) Apud Schaden, Egon, Religinto Guarani e Cristianiomo,p. 3.

(42) Schaden, Egon, Religiaro Guarani c Cristianismo, p. 5. Um notável exemplo de como elementos simb6licos do cristianismo sáo incorporados à mitologia Guarani, circunstancialmente, poderia ser o do seguinte depoimento recolhido por Egon Schaden:

" Em 1946, Pedro Pires, velho fiandeva do litoral paulista, me narrou o mito da Criaģăo, em que se diz: Era um homem. Não se sabe o pai dele e não se sabe a mãe dele. E o deus verdadeiro. Nasuderurussú. Não havia iluminaçăo no ar. Eles viviam no escuro, em cima da cruz. N̦anderovusú mandou Mbaékwáá gritar. Entz̃o ele gritou. Nanderuvusú desceu para o pé da cruz. Desceu e viu uma bolinha de terra. Á ele subiu outra vez e contou a ele que lá estava uma bolinha de terra. A ele mandou gritar ourra vez, com mais força. Al, quando ele foi, estava grande, muito grande, tinha espichado bastante, A1, o primeiro bicho que houve foi o grilo: txim, txim, txim, começou a falar. A eles desceram. Estava feito o mundo" (op. cit.., p. 13). 
adesão a um dos ramos do cristianismo de conversão: o catolicismo ou o evangelismo pentecostal. Esta confissáo de crença cristá năo raro se completa, principalmente no caso dos "guarani-católicos", com a demonstração da evidência de que a família batiza os filhos na igreja, participa de seus cultos e respeita seus santos e preceitos.

É entre eles, no interior social e simbólico da vida da tribo, que não apenas uma prática que torna atualizada a crença da religiāo dos antigos, mas também uma identidade étnica que se recompóe guarani justamente por não deixar de acreditar nos deuses e mitos da tribo, são pensadas e vividas entre todos. A exceção poderia ser, agora, a de índios convertidos por neo-missōes pentecostais. Aqui sim, comeşa a parecer crescente o número de pessoas e famílias que fazem da conversão ao cristianismo uma adesão de crença, culto e identidade. Esta nova divisáo entre os índios de uma mesma aldeia será considerada no item a seguir.

Em segundo lugar, fragmentos de crenças do catolicismo camponês são incorporados à periferia simbólica da religião guarani. No entanto, sincretismo às avessas, para que a religiāo dos ancestrais possa ser antes de mais nada justamente isso: a religiano, tais elementos cristãos populares, rearranjados de acordo com a lógica tribal, tornam-se, eles sim, elementos de crenças e cultos de medicina popular, de magia caseira, de explicaçōes parciais de relaçóes entre brancos e índios. Isto poderia significar que no seu todo o guarani vive o seu sistema original de crenças como religiăo e faz ser magia o que acrescenta a ela do cristianismo, sob a forma do catolicismo popular.

Ora, de acordo com Egon Schaden a religiáo guarani - " núcleo de resistência da cultura nas situaçóes de contacto" - apenas mantém a sua antiga integridade enquanto cada grupo, em cada aldeia, consegue preservar pelo menos a essência das regras de relaçóes entre seus integrantes. Religiáo de uma comunidade em diáspora, ela significa a própria experiência de tal vida coletiva. E quando ela perde todos ou alguns dos seus principais princípios de reorganizaçáo de estruturas e processos de orientaçáo da vida e de significaçáo do mundo, também a sua religiáo deixa de ser acreditada e vivida como um sistema integrado e íntegro de símbolos e significados.

Entre os fatores de uma progressiva desintegraçăo religiosa guarani, Egon Schaden faz coro com outros autores ao apontar: os casamentos mistos (dado que o cônjuge não-guarani dificilmente se integra em uma religiăo tribal); a imposiçáo do trabalho do índio subordinado ao poder e à lógica de patrōes brancos; a incorporaçáo à vida da aldeia $\mathrm{e}$ aos códigos da tribo de princípios regionais de ordenaçăo e atribuiçăo 
de sentido à vida social, como e principalmente, uma nova hierarquia de pessoas não mais fundada em valores internọs de base religiosa, mas em critérios "brancos", como a riqueza material.

As familias extensas, habitantes de uma mesma original casa grande, são substituídas por famílias elementares segundo o estilo regional. A subordinaçáo do tempo de trabalho ritual e de trocas cerimoniais dentro de uma aldeia, ou entre aldeias, às regras do tempo e da lógica do trabalho produtivo regido pelo interesse éconômico (traduzido pelo próprio índio como uma questão de sobrevivência) altera o esquema real de experiência do Nandé rekó. A desintegraçáo cotidiana do sistema de relaçöes entre homens e mulheres, entre pais e filhos, com os adultos em número crescente trabalhando fora das aldeias $e$ para os brancos, sugere um efeito crescente de desintegraçáo da vida religiosa guarani, que cinco séculos anteriores de catequese não consequiram abalar(43).

Três etapas desiguais poderiam traduzir o processo de transformação da vida religiosa guarani. É importante enunciá-las aqui porquanto elas revelam respostas diferentes às mesmas ou a diferentes situaçóes de contactọ e de pressáo dos brancos para a integrafáo da cultura indígena à nacional.

Uma primeira aproxima os grupos e aldeias que, apesar de todo o contacto de muitos anos com os brancos e apesar da atual

(43) Alguns dados sobre a relaçăo entre religiảo, sociedade e papéis sociais poderiam ser esclarecedores aqui. Tomo-os de Egon Schaden: "Na medida em que se pode falar em estratificaçáo social entre os Guarani, esta se baseia em critérios religiosos. $O$ prestígio do individuo decorre de seu papel nas danças e festas pelas quais se estabelece comunicaçăo coletiva com o Além. Mas tâo logo o índio, no afã de obter umas tantas coisas que antes não conhecia e agora lhe parecem indispensáveis, seja colhido pelas malhas da economia regional, começa a entrar em jogo também o ideal da eficiência econômica e 0 da posse de valores materiais. Em outras palavras: já se distingue entre ricos e pobres. E pelo fato de os homens em grande parte passarem a semana trabalhando em fazenda e outras propriedades de civilizados, é inevitável que a familia-grande, antes o principal grupo responsável pelas práticas regulares ou diárias do culto, se fragmente em famílias elementares. Para a religiảo dos Guarani sáo de importância tambem, embora de modo igualmente indireto, a ordem política e as transformaçōes que nela operam. Nas comunidades mais fiéis à tradiçāo, a chefia do grupo, originalmente composto de várias familias grandes, cabe ao pajé, cuja vida é toda voltada para o sobrenatural. Sua mentalidade o impede de compreender as exigéncias que o contacto com o mundo dos brancos trás consigo. Guardiāo da herança cultural de seu povo, provura defendê-la dos efeitos nefastos da nova situaçăo. Pouco se interessa por aprender a língua dos estranhos e mantem-se alheio a quaisquer interesses e aspiraçóes económicas que venham a manifestar-se na geraçăo dos jovens. Surgiu assim, uma nova instituição, mais condizente com a realidade atual, a do capirão, que tem entre suas funçóes principais a de representar o grupo perante a sociedade nacional. Devido às mudanças lentas mas cont́nuas e inevitéveis, o capitáo acaba por tornar-se figura de importância vital mas não entra em competiçăo com o chefe religioso, cuja autoridade e prestígio se mantém inalterados (op. cit., p. 21). Năo é difícil associar este "capităo", face da tribo ao mundo do branco, à própria maneira como os Guarani lidam com o cristianismo. Seria entăo possível dizer-se que o capitão está para o " ser cristáo" da tribo e de cada aldeia, assim como o xaña está para o "ser guarani" e afirmar-se como tal atravts da religiăo. 
subordinação do guarani aos princípios de vida e trabalho dos regionais, persistem em preservar táo intacta quanto possível a "religiáo dos ancestrais", lançando măo, inclusive, de estratégias de ocultamento de práticas rituais indígenas, de afirmaçóes "para os brancos" de adesáo ao cristianismo e de incorporaçăo fragmentada de elementos do cristianismo popular à periferia entre magia e religiảo na vida da aldeia.

Já que, para todo o Guarani, as experiências místico-religiosas constituem o objetivo último da vida, não se há de estranhar a sua dificuldade de compreender o mundo dos brancos e de nele encontrar o seu lugar. Ao passo que em outras tribos - entre os Tupi, por exemplo, os Tenentehára, do Maranhāo - arrefece aos poucos a resistência à aculturação, inclusive no que diz respeito aos valores religiosos, os Guarani se aferram a eles com obstinaçăo, embora em muitos casos já não disponham da necessária organização social para exprimi-los satisfatoriamente e torná-los efetivos(44).

Quando nesta primeira situaçăo algo do catolicismo, do protestantismo ou mesmo do espiritismo permeado de idéias e imagens de cultos de origem afro-brasileira, é incorporado à religiăo dos ancestrais, vimos que recobre aí uma dimensão simbólica liminar. Isto significa que a religião Guarani não sincretiza propriamente com outras. A cultura da tribo, para manter a integridade ainda de seu sistema religioso toma fragmentos de outras e os desloca pra esferas liminares de sua própria vida religiosa. Algo que, de resto, camponeses e operários do Brasil estão acostumados a fazer na relação entre uma identidade proclamada como católica e o uso sistemático de práticas e preceitos de cultos afro-brasileiros. Náo seria propriamente um exagero dizer que, como vimos antes, a religiấo do conquistador torna-se, na cultura do índio, a sua magia.

(44) O jogo pessoal, familiar e de aldeia em e entre religióes, como estratégia da cultura e da identidade, aproxima o índio do próprio branco pobre no Brasil. Vejamos um depoimento de Egon Schaden: " $\mathrm{Na}$ aculturação religiosa, que na maioria dos casos, como vimos, significa a aceitação de umas tantas idéias e ritos do catolicismo rural dos vizinhos brasileiros, de uma seita protestante ou de um espiritismo permeado de elementos de origem cabloca e africana, é possível distinguir três fases. Na primeira o Guarani aceita elementos estranhos sem atribuir-lhes funçăo e significado religiosos. Tem apenas valor mágico medicinal, econômico e social. Ócorre então, por exempló, como algo muito natural que o indío assista à missa e de noite participe de danças rituais na cabana de seu pagé. A presença na missa nada mais é do que fonte de prestígio nas relaçōes com a população brasileira. Levam-se as crianças para serem batizadas na igreja a fim de receberem presentes de seus padrinhos, nẫo raro pessoas estranhas à tribo, e, sobretudo, porque o evento é ensejo para uma festa. Dois motivos, portanto, o económico é o de sociabilidade. Do pecado original a ser apagado pelo sacramento o Guarani não tem noção alguma" (op. cit., p. 22). 
Em segundo lugar, fragmentos de crenças do catolicismo camponês são incorporados d periferia simbolica da religião Guarani.

Em uma segunda situação há uma efetiva mescla de sujeitos, símbolos, usos e princípios de codificação da vida entre a "religião dos ancestrais" e outras, principalmente o catolicismo e o evangelismo protestante. Ativa ainda e íntegra, a religião Guarani incorpora à sua lógica de crença e ethos elementos passíveis de gerarem associaçónes férteis, vindos de outras religiốes(45). É a religiáo tribal se pensando a si mesma, enquanto inevitavelmente se modifica através do que integra de cristáo ao seu próprio sistema.

Na terceira situação, que podemos considerar aqui como um limite, de alguma maneira o processo de articulação entre dois sistemas religiosos é oposto aos antecedentes. Agora é o cristianismo quem se impóe como "verdade cultural" e realiza entre os índios a dissoluçáo de personagens, símbolos e códigos da religiăo Guarani à sua lógica religiosa. Este momento de perda Guarani da religiáo tribal equivale, em todos os casos estudados, a uma correspondente reorganizaçáo da vida coletiva da tribo segundo os padrōes do modo de ser indígena.

\section{Quando os estudiosos de religiáo na América do Sul falam de} sincretismo, algumas vezes cometem duas falhas que uma análise da religião indígena em contacto com culturas regionais ajuda a corrigir.

Năo são sistemas religiosos em si mesmos, postos em relaçáo, os que intercambiam elementos de troca e que, como resultado, produzem amálgamas peculiares ou sub-sistemas religiosos. Em tudo há - e a experiência Guarani dramaticamente o revela - situaçóes vividas entre sujeitos religiosos ou não, de um lado e do outro. Há estratégias e processos sociais de alianças táticas e de conflitos inevitáveis, de expropriações e de apropriações. Não são apenas "elementos" de religiōes que se aproximam e se fundem, que se combinam para produzirem outra coisa que não mais eles mesmos. $O$ que existe é a criação de novas articulaçōes de e entre sistemas integrados de símbolos e significados religiosos. Processos de subordinaçăo e domínio também entre os símbolos e seus valores; recriaçōes lógicas e possibilidades de recriação de rearranjos dentro de uma mesma religiăo, ou na fronteira entre ela e uma outra.

Mais do que sincreticamente criar uma religião, ou um sistema variante em uma única direçăo, o que parece ocorrer no caso Guarani é

(45) Sigo com Egon Schaden: "Na segunda fase se aceitam padróes de comportamento, símbolos e conceitos religiosos enquanto tais, mas reinterpretando-os em termos de religiăo tribal e sobre a base de analogia. A divindade suprema é identificada com o Deus cristāo e recebe o nome de Nande Djara, Nosso Senhor. Outros entes sobrenaturais se equiparam a santos católicos, à semelhança do que se deu nas religióes afro-brasileiras. Os anjos cristăos săo ymyrái dja, os espíritos auxiliares. Com o batismo cristão acabam por confundir-se as cerimónias pagãs de nominação, nas quais se integram, aliás, elementos do tempo dos jesuitas" (op. cit., p. 22 e 23). 
um jogo de relaçōes de resistência e subordinação. Se em um primeiro momento a religião da tribo preserva a sua integridade "religiosa" às custas de deslocar para sua fronteira, como magia utilitária, os valores e princípios de usos de culto de outras religióes, em um segundo momento, ainda articulada e dominantemente a religião tribal reordena seu próprio logos para pensar-se a si mesma através do que integra de uma outra religião, cujo sistema dissolve em sua própria lógica: em e como seu sistema religioso. Se a idéia de sincretismo é ainda válida, podemos falar aqui de uma subordinação do cristianismo a uma lógica sincretizante indígena.

Apenas uma terceira situaçăo limite poderia corresponder ao que tradicionalmente é descrito como um efeito de sincretismo, quando uma cultura já cristianizada - isto é, cujo sistema religioso de crença e vida já é o cristão - deixa-se impregnar de "elementos nativos e se realiza com a mescla deles, quando năo gera, de uma possível e discutível combinaçáo de duas ou mais religiōes, uma outra, diversa de todas(46).

Vejamos a seguir como, em um caso concreto, não mais uma cultura indígena, mas os seus personagens lidam com a identidade religiosa $\mathrm{e}$ suas transformaçóes.

\section{Guarani: índio católico $\mathrm{x}$ índio crente}

Há uma curiosa divisão com que se diferenciam os sub-grupos Guarani do Litoral de São Paulo, entre Itariri, no Sul e Ubatuba, na fronteira Norte com o Rio de Janeiro. Os índios do sub-grupo Nandeva auto-identificam-se com "guarani" e aceitam com os Mbüa a classificação de "tupi", para este sub-grupo(47). Havendo chegado antes, os Ñandeva reconhecem-se também como" índios dãqui", isto é, do lugar, e atribuem aos Mbüa serem vindos do Sul do país, muitos anos depois.

Provenientes possivelmente do Paraguai, do Mato Grosso e dos estados do Sul do Brasil, esses guarani do litoral paulista serão a sobra das grandes migrações anotadas por Kurt Nimuendajú em 1824, 1870 e 1912. Terão vindo também, em bandos menores, em anos posteriores do presente século. Eles estáo hoje estabelecidos em $\mathbf{5}$ aldeamentos nas matas do litoral e em dois acima, no planalto da Serra do $\operatorname{Mar}(48)$.

(46) Sobre esta questão remeto leitor ao oportuno estudo de Manuel Estevez Gutierrez: En torno al estudio comparativo de In pluralidad católica.

(47) Cherobim, Mauro, Os indios Guarani do Litoral do Estado de Săo Paulo, p. 27.

(48) Id.Ibid. pg. 65-78. Sobre o que representam os " aldeamentos" Guarani para os índios do litoral, ver p. 82 . 
Insulados e pequenos aldeamentos que em nada significam a posse de reservas adequadas e definitivas, os Guarani procuram preservar ainda a sua principal atividade de subsistência: a caça, acompanhada de pesca e coleta. São reconhecidamente mais hábeis que os caçadores brancos, caiçaras e caipiras, que os acusam de dizimarem os animais da floresta. Praticam uma agricultura complementar com base no milho e na mandioca. Ela é maior e integra mais a dieta dos sub-grupos Ñandeva do que dos Mbüa. Habitantes ainda de florestas em uma regiáo destinada recentemente ao turismo e que muito depressa sofre modificaçóes demográficas e econômicas, os índios até agora são muito pouco requisitados como força de trabalho no mercado regional. Sua principal atividade é a produçáo de artesanato para a venda(49).

Não há mais uma terra para onde viajar, além do oceano a cuja beira chegaram, muito embora o mito da Terra Sem Mal esteja presente até mesmo na fala cotidiana dos Guarani Ñandeva ou Mbyá.

Vejamos como em uma situação localizada a duplicidade religiosa é vivida e representada na cultura Guarani. Persistente no desejo de manter autônoma a cultura da tribo, mas inevitavelmente inserido sem em absoluto reconhecer-se integrado na sociedade regional, o Guarani pensa a religião como uma experiência de dupla dimensão: existe a "minha religiāo", a "nossa religiāo", algo como o ñande rekó que se assume como sendo a religiáo guarani, a "religião dos antigos"; existe o cristianismo, reconhecido como: "a igreja católica" e a "dos crentes".

Seria possível falar-se de uma religião interna, a dos índios, reconhecidamente entre eles, e de uma religiáo externa, se os dois qualificadores não parecessem algo artificiais. Pois a realidade da oposição está além desta mera geografia. Disse algumas páginas atrás que o sistema religioso Guarani é aceito pelos índios como o núcleo simbólico das crenças e da identidade indígena. É a religião de que seé, o fundamento da própria cultura naquilo em que, para o Guarani, apenas em aparência isto ou aquilo nada têm a ver com a própria religiáo. De modo mais motivado entre estes índios do que entre vários outros do continente, é impossível pensar em ethos e uma visão de vida Guarani e dos Guarani sem ser através da religiăo. Deste modo, mesmo um índio convertido de corpo e alma a uma confissão

(49) "Todas as atividades dos Guarani săo voltadas para uma arividade principal, que é a confecçăo de produtos artesanais destinados à comercializaçăo. Pronta uma certa quantidade, enfeixam-na e iniciam a venda pelas imediaçóes do aldeamento, praias, estradas, indo à capital de São Paulo. Quando vendem tudo retornam para casa e o trabalho recomeça". (op. cir., p. 109). 
pentecostal e, portanto, negador como sistema denoníaco de sua antiga religiáo, ela ainda é a religiảo da sua tribo. Mesmo teologicamente falsa (e entre eles muita discussáo a respeito deve haver) ela é metaforicamente o eixo da verdade da tribo, porquanto o Guarani é a sua religiāo.

Eis porque a religião dos antigos funciona - e como poderia deixar de ser assim? - como um sistema de valores guardiāo da unidade da tribo, na diferença entre seus sub-grupos.

Assim, a religiảo tribal é, em última análise, um dos elementos aglutinadores do grupo enquanto expressáo étnica onde o Guarani encontra solidariedade tribal em termos de segurança, apoio, auto-identificaçäo, etc. Neste sentido, esta dimensão religiosa é sinônimo de dimensăo índia de vida do Guarani(50).

Se o Guarani se reconhece como tal através de crer e procurar praticar a "minha religiāo", ele aceita ser cristão. Aceita relacionar-se para fora da aldeia e da tribo com os brancos, como um cristão: catolico ou crente. Atençáo, mesmo em aldeias onde o trabalho evangelizador atual é fraco ou inexistente, uma proclamaçáo de adesáo ao cristianismo parece atualizar entre os índios, frente aos brancos, a legitimidade das relaçóes entre as duas culturas. Pois se em absoluto não cabe ao branco converter-se a, ou mesmo reconhecer a religião Guarani, ao índio é necessário proclarmar-se cristão para reconhecer-se capaz de colocar-se diante do branco. Uma apressada interpretaçăo utilitária que visse nesta duplicidade uma apenas estratégia consciente e adequaçáo a um modo inevitavelmente dual e opressor, perderia de vista uma razão mais densa(51).

Uma vez mais, estejamos atentos, náo se trata de um puro e simples sincretismo religioso, mas de uma duplicidade confessional que sugere a cada sistema de crença e culto não apenas uma funçăo, mas a atribuigáo de significados a uma dimensáo desigual de experiência de relaçóes sociais e simbólicas da própria vida cotidiana.

E aqui a diferença sobre como se comportam, como sujeitos religiosos, os índios convertidos a uma das ramas do protestantismo, ou reconhecidos como católicos, poderia esclarecer mais de perto o jogo desta própria inevitável duplicidade.

(50) Cherobim, Mauro, Os tudios Guarani do Litoral do Estudo de Sto Paulo, p. 124.

(51) Id Ibid. Ver anditise frito das p. 124-30. 
Se pudéssemos colocar como um tipo puro da religiáo tribal a pessoa Guarani que ativamente recusasse todo e qualquer reconhecimento em si mesmo do cristianismo, teríamos que colocar no extremo oposto o convertido ativo ao protestantismo pentecostal. Oculto o primeiro, proclamado o segundo, de acordo com o bom estilo "crente", os dois rertamente existem, encarnados em sujeitos, em modos confessionais de ser: o primeiro cada vez mais a exceção, o segundo como uma crescente e perigosa demografia ativa. Porque eis que o sujeito religioso apenas Guarani existe como um ser de cultura, no interior da tribo, entre seus silêncios e segredos, não como um índio entre brancos, que é como cada vez mais os Guarani sáo obrigados a sobreviverem. Extremo oposto, o "índio-crente" precisa afirmar para os brancos e entre eles a sua exclusiva adesáo à nova fé cristá. Isto porque não existe outra modalidade de se ser pentecostal que não seja o reconhecimento de uma adesáo indiscutível a uma única igreja de uma única religiáo tida como verdadeira e redentora.

Mas eis que mesmo alguns convertidos ao protestantismo continuavam considerando a religiăo tribal como "a verdadeira",

Năo seria propriamente um exagero dizer que, como vimos antes, a religitio do conquistador torma-se, na cultura do indio, a sua magia ainda que não mais, ativamente, a religiāo deles, crentes. Seria entáo a religiáo Guarani uma verdade voltada ao passado, imobilizada em sua vocaçáo de não se mesclar ou render aos cultos dos brancos, sendo, ao mesmo tempo, incapaz de trazer ao índio de agora, na situaçáo de sujeiçáo em que vive, a resposta de uma salvação antes acreditada e agora, desesperada.

Uma mulher do aldeamento de Itariri, ao ser indagada porque era "crente", respondeu "porque eles passaram por aqui e disseram que Jesus vinha nos salvar". Ingressou na igreja, mesmo sem condiçóes de frequentá-la por razóes de saúde que impossibilitaram seu deslocamento. Seu marido e os outros membros do aldeamento eram assíduos aos cultos. Respostas idênticas recebemos em Boissucanga e em Ubatuba: convertiam-se à espera de salvação. No entanto, estes mesmos informantes "conversos" sempre se referiam à religião tribal como a verdadeira; a conversáo possibilitava poder manipular uma situação à qual os índios se sentiam impotentes; convertidos, diziam que "agora eu náo incomodo ninguém, e agora ninguém me incomoda" (52).

(52) IdIlid. p. 139. 
Mas certamente não será esta pobre razáo funcional o que explica o porque de conversóes crescentes de Guaranis ao protestantismo pentecostal. Uma associaçáo entre o seu discurso de salvaçáo, de resto náo muito distanciado simbolicamente da busca da Terra Sem Mal, como um precário sucedâneo branco ao mito indígena, poderia ser aqui feita com o profetismo Guarani. Claro, ela nega a essência simbólica e histórica deste mesmo profetismo, principalmente por delegar mitos, valores, acontecimentos e sujeitos não-indígenas um projeto de busca não apenas Guarani - isto $\hat{e}$, essencialmente indígena - mas com exclusividade para os Guarani, ou seja, para os não-brancos, para os que "foram enfeitados" (53).

Entre os dois tipos extremos propostos aqui, reais ou năo, o Guarani-católico poderia ampliar a compreensáo do que se discute. Tal como acontece com os próprios brancos - os camponeses vizinhos dos Guarani, em todos os países do Sul do continente onde eles estáo, por exemplo - a possibilidade real de se apresentar como um católico e compartir com tal identidade proclamada outros sistemas religiosos ou, pelo menos, alguns serviços e momentos de outras religióes, é uma hipótese não apenas viável, mas até costumeira.

Mesmo entre os "guarani-crentes" há queixas dos pastores brancos de que eles são volúveis: mudam de uma para outra igreja e não raro se afiliam a mais de uma, algo impensável na lógica protestante(54). $O$ que parece ser problema para a fração guarani convertida ao pentecostalismo: assumir-se crente e aceitar na prática a verdade da religifío dos antigos (o que é diferente de, no interior da aldeia, reconhecê-la como verdadeira, pelo menos no âmbito do mundo Guarani), é uma solução não pressentida como contraditória para o guarani-católico.

A descontinuidade exigida pelas igrejas protestantes entre sua fé e a dos índios năo encontra um equivalente no caso católico, nem como atitude ativa por parte da igreja próxima aos índios, nem - e principalmente - na lógica do catolicismo popular. Vejamos. Quando um Guarani vem a converter-se sozinho ou com a família a um grupo pentecostal, será dele exigido pela nova confraria religiosa de adesáo um comportamento exemplar, negados os modelos incompatíveis da

(53) Eis que inteligentemente Mauro Cherobim năo resiste associar a oposiçăo "Terra Ruim" versus "Terra Sem Mal" dos Guarani, ao desenho conhecido e costumeiro dos "dois caminhos", com que os protestantes atualizam as duas vias únicas do destino do homem: o "caminho largo" de perdiçăo, cujo contexto visual é todo ele urbano, e o " caminho estreito da salvação, eminentemente rural. Ver p. 134-9.

(54) Id.Ibid. p. 140 e, especialmente, a nota de rodape 27. 
cultura guarani, negados ainda mais os do catolicismo camponês, aceitos apenas e com restrita exclusividade os do padräo protestante de crença, culto e conduta social. Eis um exemplo de conversão não apenas a uma confissáo religiosa, mas a um modo radical de vida regido por uma neo-religiáo.

Pois se em absoluto não cabe ao branco converter-se a, ou mesmo reconhecer a religiäo

Guarani, ao indio é necessturio proclamar-se cristão para reconhecer-se capaz de colocar-se diante do branco.

As seitas protestantes, principalmente as iluministas ou pentecostalistas, prescrevem um código de comportamento moral com proibiçóes de vícios e estímulos à vida correta e produtiva. Fabricam, assim, uma imagem de uma criatura puritana, muito compatível com as idéias capitalistas de vida. daí a melhor aceitaçáo, pelo civilizado, do índio-crente e a sua valorização no contacto político manipulado pelo branco. A "conversáo" de Bento faz mudar os motivos da sua contestação como lider: deixou de ser o beberrão e passou a ser contestado "por não ter cultura" (55).

No intervalo entre a face mais xamanística e menos profética da religião guarani e o catolicismo popular sincretizado, a cultura dos ñandeva dá margem até mesmo para a incoporaçáo de elementos de cultos afro-brasileiros, desde que o conjunto se perceba subordinado à "verdadeira religiāo": a guarani(56).

Quando um Guarani é convertido a uma igreja protestante, os brancos e os seus neo-irmãos de fé exigem dele uma conduta que, ambivalente ao negar o ethos e o modo de ser propriamente guarani, como um suposto tipo puro de sujeito indígena, negue aquilo que caracteriza $o$ guarani-católico: a idolatria, os vícios do álcool e "da carne", o recurso as atividades mágicas, a não subordinação do tempo da pessoa a um código de vida regido pelo trabalho, onde a própria caça atividade guarani ancestral - é mal vista, porquanto é um não-trabalho. Pelos guarani não-crentes, o convertido é desqualificado por haver abdicado publicamente não apenas de usa religiăo de origem - o que ele faz com dificuldades, vimos - mas de um modo de ser em sua essência incompatível com os valores protestantes.

De um lado e do outro das duas margens que o cristianismo oferece

(55) Id.Ibid. p. 141.

(56) "Nesta entrevista, entretanto, duas coisas ficaram patentes: e foi influência de cultos afro-brasileiros: o rezador se situava como pertencente a uma "linha", provavelmente de "caboclo", que a denominava de "índio guarani"; havia uma forte reaçáo a outras religiobes, sempre reafirmando a sua, tribal, como a verdadeira" (IdIbid, p. 142). 
ou impóe ao Guarani como saída simbólica a uma incorporação do sujeito índio ao mundo do homem branco, subsiste uma estranha vocação de guarda da integridade da religiáo ancestral. Em outras situaçōes de conversão de sujeitos, famílias e grupos inteiros de indígenas latinoamericanos a confissões cristãs, năo é raro que, fragmentado e subalternamente sincretizado, sobretudo com $o$ catolicismo, a religião tribal se reduza a um repertório de preceitos e usos de tipo mágico. A tribo adota ou representa haver adotado uma religião dos brancos e, nos limites em que ocultamente pode fazê-lo, revive fragmentos de sua religiăo antecedente.

No caso Guarani parece haver uma vocação oposta. Ela consiste em reduzir e em magicizar a religiăo de conversão e afirmar ainda a integridade e a excelência da religiáo tribal como um sistema não redutível e crenças e cultos próprios da tribo. Seja reconhecendo tal sistema indígena como a verdadeira religião, para os índios, como entre os "crentes", seja vivendo-a na plenitude possível, sob a capa de uma confissáo católica, é a religiđo Guarani que se trata de não integrar, isto $\hat{e}$, de não deixar corromper-se no confronto com a do homem branco, "não enfeitado", " não eleito", ainda que dominador(57). A própria "mescla" com elementos religiosos do catolicismo popular ou de cultos de origem afro-brasileiras realiza-se, vimos já, segundo os padróes de incorporação do novo e as possibilidades de transformaçăo própria da lógica e da vocaçáo religiosa guarani.

Eis um caso raro em que a demografia de conversáo ao cristianismo favorece não o desaparecimento ou à descaracterizaçáo da religiáo tribal, mas justamente o contrário: o desejo persistente de sua reinvençăo e a afirmaçăo de sua perenidade.

Pudemos observar exatamente isto nas últimas viagens realizadas ao Bananal, uma tentativa de retorno às tradiçóes tribais, em busca compensatória para a descaracterização trazida pela aculturaçăo. A casa-de-rezas foi reativada e os cerimoniais passaram a ser realizados com frequência e assistidos náo só pelos ñandeva locais, como também pelos Müa do aldeamento da

(57) O que quer dizer esta possibilidade, quando mesmo entre os povos missionários catolicos, pós-conciliares e defensores de uma Teologia da Inculturaçāo, em que a própria religiảo tribal é para ser defendida e valorizada, como uma reversăo absoluta - pelo ymenos no plano da intençảo - do projeto catequético? Ver, a respeito: Inculturááño - Libertafato edirado pelo Conselho Missionário Indigenista, com o apoio da própria Conferência Nacional dos Bispos do Brasil. 
Barragem. Apresentam, no decorrer dos cerimoniais e pelas declaraçóes do chefe religioso, um sincretismo com traços afro-brasileiros...

Verificamos nesta pesquisa que, pelo menos em relação aos Ñandeva, a religiâo, neste momento, deixa de ser apenas individual e/ou familiar para se tornar religiáo de todo o grupo e, como tal, fazer parte do movimento contra-aculturativo grupal(58).

Bibliografia

BARTOLOMÉ, Miguel Alberto. ' La Situación de los indígenas en la Argentina: área chaqueña y Provincia de Missiones' . In: W. Dostal e G. Grunberg. La situación del indigena en America del Sur (aportes al estudio de la fricción inter-émica en los índios nos andinos), Montevideo, Biblioteca Cientffica, 1971.

CADOGAN, Leon. ' La tradiciones religiosas de los índoios Jeguará Tenondé Porá Gué y del Guaira comúnmente llamados Mbyá, Mbya-Apyteré o Kaynguá' . In: Revista de La Sociedad Ciontifica del Paraguay, VII, I, Assunción, 1946, p. $15-47$.

CENTRO ECUMENICO DE DOCUMENTAÇĀO E INFORMAÇĀO. Povos Indígenas no Brasil/83: Aconteceu - especial 14, São Paulo

CENTRO ECUMENICO DE DOCUMENTAÇĀO E INFORMAÇĀO. Povos Indígenas no Brasil/84: Aconteceu - especial 15, São Paulo

CENTRO ECUMENICO DE DOCUMENTAÇÃO E INFORMAÇÃO. Povos Indígenas no Brasil/84: Aconteceu - especial 17, São Paulo

CHASE-SARDI, Miguel. ' La situación actual de los indígenas en el Paraguay' . In: W. Dostali e G. Grunberg. Op. cit.

CHEROBIM, Mauro. Os indios Guarani do litoral do Estado de Säo Paulo: análise antropológica de uma situação de contato. São Paulo, FFLCH/USP, coleção antropologia, 1986

CLASTRES, Hélène. Torra Sem Mal. Săo Paulo, Editora Brasiliense, 1978

CLASTRES, Pierre. A Sociedade Contra o Estado: pesquisas de antropologia política. Rio de Janeiro, Francisco Alves, 1978.

CLASTRES, Pierre. Chronique des indiens Guayaki. Paris, Plon, 1972.

COELHO dos Santos, Silvio. 'A situação dos indígenas no sul do Brasil' . In: W. Dostal e G. Grunberg. Op.cit.

DIAZ, Noemi Martinez. · La migración Mbya (Guarani)' . Dédalo, 24, São Paulo, Museu de Arqueologia e Etnologia/USP, 1985, p. 147-69.

GUTIERREZ ESTÉEEZ, Manuel. ' El torno al estudio comparativo de la pluralidad católica' . In: R.E.I.S., 27, Madrid, 1984.

KELM, Heina. ' Grupos indígenas de Bolívia' . In: W. Dostal e G. Gunberg. Op.cit.

KIETZMANN, Dale N. · Indians and culture areas of twentieth century - Brazil. Culture área IX: Paraná. In: Indians of Brazil in the twenticth century. Washington, Janice Hopper ed., Cross Cultural Research, 1974.

LARAIA, Roque de Barros. Tupi: Indios do Brasil atual. Săo Paulo, FFLCH/USP, coleçāo antropologia, 1986.

(58) Cherobim, Mauro, IdIbid.p. 86-7.

Estudos Avançados, 4(10) 
MAZZOLENI, Gilberto. 'Huave: la rifondazione quale constanze' . In: L'America Rifondata - analisi di tre risposte indigene alloccidente. Roma, La Goliardica Editrici, 1981.

MELIÁ, Bartolomé e MUNZEL, Christine. ' Ratones y Jaguares' . In: Bastos, Augusto Roa (ed.). Las Culturas Condenadas. México, Siglo XXI, 1978.

MELIÁ, Bartolomé, VINICIUS DE ALMEIDA, Marcos Saul, MURARO, Vlamir Francisco. O Guarani: uma bibliografia etnológica. Santa Maria, FUNDAMES/Pró Memória, 1987.

MELIÁ, Bartolomé. ' El modo de ser Guarani en la primera documentación jesuítica (1549/1639)' . In: Revista de Antropologia, vol. 25, 1981, p. 1-24.

METRAUX, Alfred. 'The Guarani' . In: Handbook of South America Indians. Washington, Steward, J. ed., Bureau of American Ethnology, bulletin 143 III, 1948, p. $69-94$

METRAUX, Alfred. A religiño dos tupinambdis - e suas relaçōes com a das demais tribos tupi-guaranis. São Paulo, CENAC/EDUSP, 1979.

NIMUENDAJU, Kurt. Los mitos de creación y de destruición del mundo como fundamento de la religión de los Apapokupa-Guarani. Lima, Centro Amazonico de Antropologia y Aplicación Pratica. 1978.

POMPA, Cristina. ' Il Mito dela terra senza male' . In: L'America Rifondata. Op.cit.

SCHADEN, Egon. Religião Guarani e Cristianismo. São Paulo, Revista de Antropologia, vol. 25, 1982, p. 1-24

VARIOS autores. Inculturação e libertação. São Paulo, CIMI/CNBB, Ed. Paulinas, 1986. 